\title{
Hydraulic and urban management during Roman times based on GIS and remote sensing analysis (Clunia, Spain)
}

\section{Organització hidràulica $i$ urbana en època romana, basada en una anàlisi GIS i de teledetecció (Clunia, Espanya)}

The Roman city of Clunia (nowadays at the Spanish province of Burgos) became the capital of the Tarraconensis conventus with the Augustan provincial reform, which provided a major boost for its urban development. The suitability of the city's location is evident by the fact it was built on a plateau concealing an underground karst cave that provided direct access to water without requiring major engineering works. The waters in this cave were used and administered by the people, and some of its galleries acted as a shrine for worshipping.

This study provides an overview of the modern drainage systems in order to study more profoundly the forms of urban organization, on which we have only partial knowledge currently, given the breadth of the field. We believe that some of these drains are actually tracks of ancient streets that have been fossilized in orography. To reach these conclusions, we analysed several IR photographs, and applied hydrological GIS functions to observe the path of these tracks and their relationship to what is currently known of the city's urban layout. This analysis of the surface was completed by relating it to the karst topography by conducting geophysical surveys in areas where wells giving access to the cave were detected using radiolocation. Finally, we applied a range of hydrological GIS functions and indexes on a high-resolution DEM obtained from LIDAR technology ( $5 \mathrm{~m} /$ pixel), to confirm how the drainage worked.

The results have highlighted landforms on the plateau, providing new hypotheses about Clunia's urban development. Repetitive modulations were also observed in the distances between some of the drains, thus making for a better understanding of the characteristics of an entire sector of the ancient city. We therefore believe that the drainage calculation method may be a useful tool for the study of urban structures that have not been excavated yet.

Keywords: Remote Sensing; Drainage System; GIS; Hydrological Index; Roman Archaeology.
La ciutat romana de Clunia (avui dia a la província de Burgos) esdevenia la capital del Conventus Tarraconensis amb la reforma provincial augustiana, la qual va proporcionar un impuls important al seu desenvolupament urbà. La idoneïtat de la ubicació de la ciutat és evident pel fet que va ser construïda en un planell que encobreix una cova càrstica la qual va proporcionar accés directe a l'aigua sense requerir feines d'enginyeria de gran importància. Les aigües d'aquesta cova van ser usades i administrades per la ciutat, i algunes de les seves galeries van servir de santuari.

Aquest estudi proporciona un resum dels sistemes de drenatge moderns per tal d'estudiar més profundament les formes d'organització urbana de la colònia romana, de la qual només tenim un coneixement parcial. Creiem que alguns dels drenatges moderns són de fet indicis de carrers antics que han estat fossilitzats a l'orografia. Per assolir aquestes conclusions, vam analitzar fotografies d'infrarojos, imatges de satèl.lit, i es van aplicar funcions GIS d'hidrografia per tal de veure el traçat d'aquests drenatges i la seva relació amb el que actualment es coneix del traçat urbà de la ciutat.

Aquesta anàlisi va ser completada amb topografia del carst, identificant a través d'estudis geofísics els pous que donaven accés a la cova, prèviament identificats per radiolocació. A la fi, vam aplicar una sèrie de funcions de càlcul hidrològic sobre un DEM d'alta resolució ( $5 \mathrm{~m} /$ píxel), per confirmar el funcionament dels drenatges.

Els resultats proporcionen hipòtesis noves sobre el desenvolupament urbà de Clunia. S'han observat modulacions repetitives entre alguns drenatges que permeten entendre millor les característiques d'un sector sencer de la ciutat antiga. Per això creiem que el mètode de càlcul del drenatge pot ser una eina útil per a l'estudi d'estructures urbanes que no han estat excavades encara.

Paraules clau: teledetecció, sistema de drenatge, GIS, índex hidrològic, arqueologia romana. 


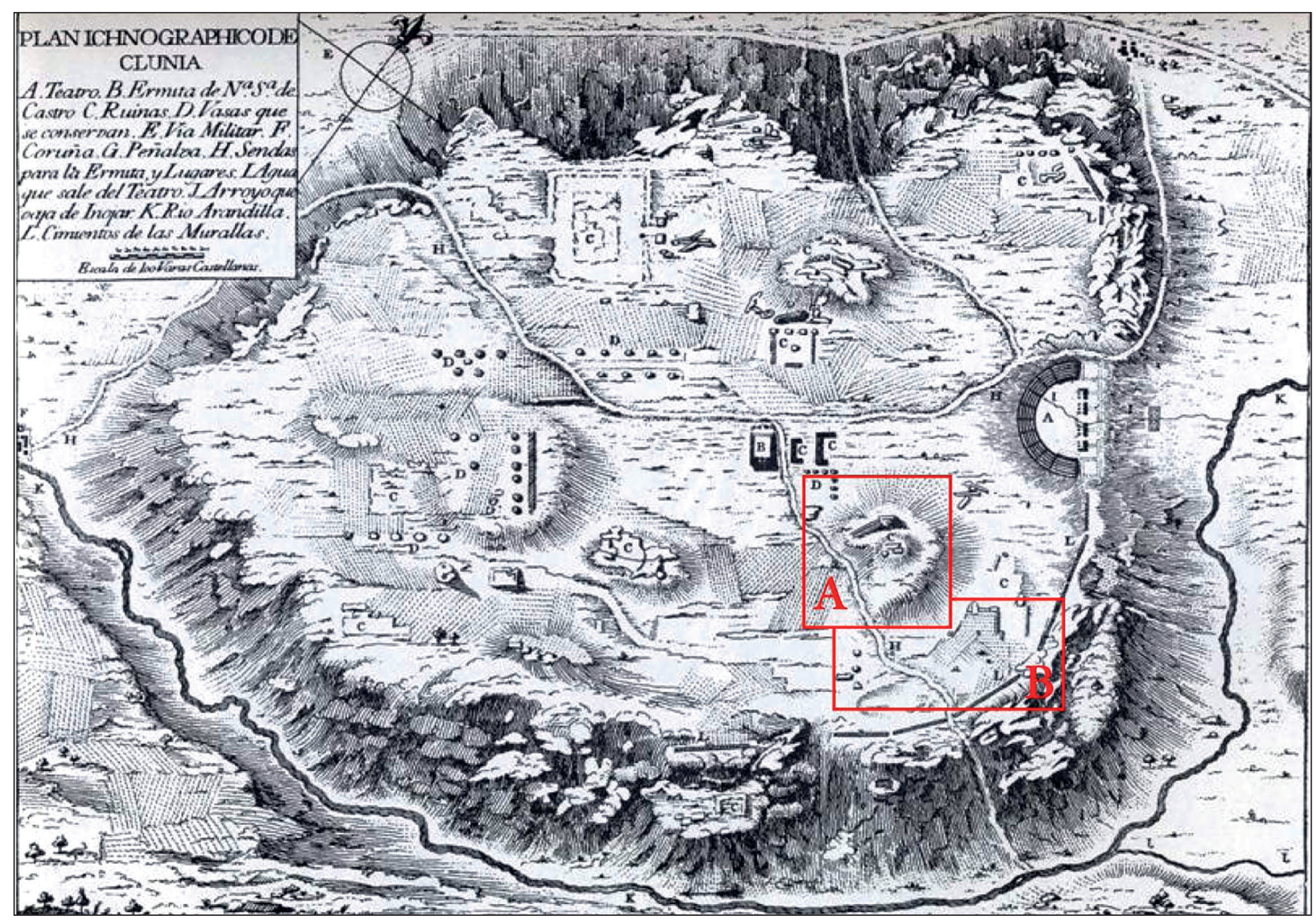

Figure 1. Juan Loperráez's sketch of Clunia. Labels A and B correspond to the areas that will be covered in detail in this article (Loperráez Corvalan 1788: 321).

\section{Introduction}

\section{Historical Context}

When considering the history of Clunia we need to take into account that it was a city written sources offer scarce information about. We know that it was one of the most important cities of the Arevaci; its name is mentioned for the first time in accounts of the Sertorian War. After the Augustan administrative reform, the city became an important centre for legal and territorial Romanization as a conventus capital because of its location on the routes to western Spain. Clunia was one of the first cities on the central plateau to achieve municipality status. However, the city had primarily a representational role of the Roman administration, without a solid economic foothold in the territory, which led to its slow decline. Afterwards, Clunia was forgotten to such an extent, that locating it proved difficult for the first researchers who turned interested in the city's history in the $16^{\text {th }}$ and $17^{\text {th }}$ centuries. Juan Loperráez Corvalan was the first to locate the ancient city, and drew a sketch (Fig. 1) with the architectural remains that were still standing in 1775.

This drawing is one of the sources of information to be considered throughout this article, to contrast the results of the different methodological approaches in the Discussion section. Our research will specifically focus on two areas of the site (Fig. 1, labels A, B).

The excavations of the city with a long scientific tradition, have brought to light an interesting set of monuments scattered over the hill without an apparent order. That is why our archaeological research focuses on finding the consistency of this distribution. This analysis seeks to link the urban design with the position of the aquifer and the main drainage system of the hill. However, the approach to the search for this connection is intended to be done using non-invasive techniques such as various functions provided by GIS, satellite images, LiDAR data visualization techniques, etc.

\section{Methodological approaches}

From this point of view, there is already extensive literature on the matter, and so far the exploration capabilities of GIS and remote sensing have advanced in general (for instance (Rolawnds and Sarris 2007; Gallo et al. 2009; Alexakis et al., 2011), although it is interesting to accent on new contributions such as the conducted by Traviglia and Cotica (2011). Their project consisted of the recovery, protection and eva- 
luation of the historical and archaeological heritage of Constanciacus, an ancient small group of islands in the Northern Lagoon of Venice, of which currently only two emerged strips have survived. Cooperation between archaeologists and experts in remote sensing in this case was critical for investigating the extent and geomorphology of the ancient islands. Aerial photographs, (both vertical and oblique), ancient maps, and HR satellite images were used to identify past traces of occupation that remain buried now.

Furthermore Jiménez Sánchez et al. (2011) described the methodology, findings and interpretation of the short-term, rescue-archaeological survey based on a multidisciplinary research, driven by geomorphologic approaches. In his paper, we see both the advantages of GIS as a catalyst for spatial information landscape, and some of the most basic functions derived from a DEM. The data obtained comes from applying methods as diverse as Ground Penetrating Radar, Palynology, or studying the morphology of the landscape through aerial photography. The methodology used is interesting as evidence for the entire time sequence of the affected area in question. However, the combination and application of these methods was described in a certain way by the work of Brown (2008), reporting on two case studies demonstrating the ability to integrate GIS using LIDAR to generate high resolution DEM, the use of geophysics, particularly ground penetrating radar, and electrical resistivity, to produce sediment depth models. These techniques, along with more systematic and detailed sedimentological recording of exposed sections, have allowed the construction of more precise 3-dimensional (volumetric) models of the matrix of artefacts within fluvial deposits.

\section{Settings}

\section{Regional Context}

Clunia (Fig. 2) is located in the area around the village of Peñalba de Castro, and more specifically on El Alto de Castro, a hill at the bottom of which the modern urban settlement was situated. The largest modern settlement near what might have been the municipality of Clunia, is Peñaranda de Duero, followed by Caleruega, and Huerta de Rey.

The climatic characteristics defining this area of the central plateau of Castile fall within the region known as Iberia Verde Continental Extremada (Font Tullot 1983). This designation is used to refer to an area where the vegetation and crops are those of an extreme climate: low and freezing temperatures in winter (more than 75 days between the months of October and May), and short but very hot and dry summers. Annual rainfall ranges from 500-800 $\mathrm{mm}$, but there are significant variations between the areas with an average altitude around $920 \mathrm{~m}$, or the foothills of the Iberian Chain, more than 1,100 m high. The rainfall distribution is irregular throughout the year, with a peak of intensity from October to May (Rodríguez Fernández and Heredia 2007: 42-43). According to the classification of Papadakis (1966) the climate of the area pertains to the continental semiarid Mediterranean type, with a semi-warm temperature regime.
The municipality's area of influence is clearly influenced by its proximity to the Duero Valley, which determines the characteristics of a landscape with a gentle relief, which only changes in the north due to the foothills of the Sierra de la Demanda Mountains. Within the Duero Basin, the study area covers the region known as El Alto Duero, characterized by its limestone plateau relief containing the rivers network, leading to levels of terraces and flat-bottomed valleys, as well as more vertical slopes around the secondary network. Around Clunia, the Duero river model includes the lower courses of the Arandilla, Perales, Pilde, Bañuelos, Aranzuelo, and Espeja rivers.

Duero's tertiary depression is a geomorphological unit of tectonic origin, and is almost completely surrounded by a rim of pre-Tertiary rocks that reach altitudes exceeding $2,000 \mathrm{~m}$. The Duero river region constitutes a large basin, which during the Tertiary period filled up with Paleogene and Neogene alluvial and lacustrine detrital sediments. The end of Tertiary sedimentation is marked by the onset of the Quaternary drainage system. The new external fluvial forces produced massive erosive breaks in the sequence, and the action of rivers and the resistance of the calcareous levels to erosion have modelled a characteristic landscape defined by three morphological elements: river valleys, escarpments, and plateaus (Díez Martin 2010).

We know that the city was located on the tertiary sediments of continental origin in the Duero Basin, where clay and sand alternates, and was covered by 20 metres of limestone from the Pontiense period. These Miocene sediments, which date back to between 5 to 7 million years, were deposited in the continental basin and remained unchanged when they came to rest on the Mesozoic base. This land is favourable for the filtration of rainwater into the clay layers surrounded by the limestone, as can be seen in the geological survey of the hill conducted by Valdés and Reina (Valdés and Reina 2004; Valdés et al. 2004). This study determined the existence of a fault, or fracture that marks two points with evidence of hydrological activity at the edge of the plateau, suggesting the existence of two sectors: the Theatre Sector, and the Cueva Román Sector (Fig. 3).

In the Cueva Román sector areas of water activities were identified, both in the areas of greater thickness of the limestone layer, and in those of lesser thickness. To the west, there is an upwelling, probably active throughout the year since it has water in times of drought (July, August, and September). It is a partially underground spring.

The water outlet in the Theatre sector was considered as being distinct and independent of Cueva Román. Geologically it is noted that this upwelling occurs in the contact area between the marl and limestone package, at a height of $989 \mathrm{~m}$. The water flows in various parts of the cavea, so it must have been a problem already at the time the theatre was built. A Roman drain under the cavea carries water through the foundation outside of the building (Valdés and Reina 2006). 
R. Cuesta, I. Fiz, E. Subias, F. Tuset, M. Á. de la Iglesia, Hydraulic and urban management during Roman times based on GIS..
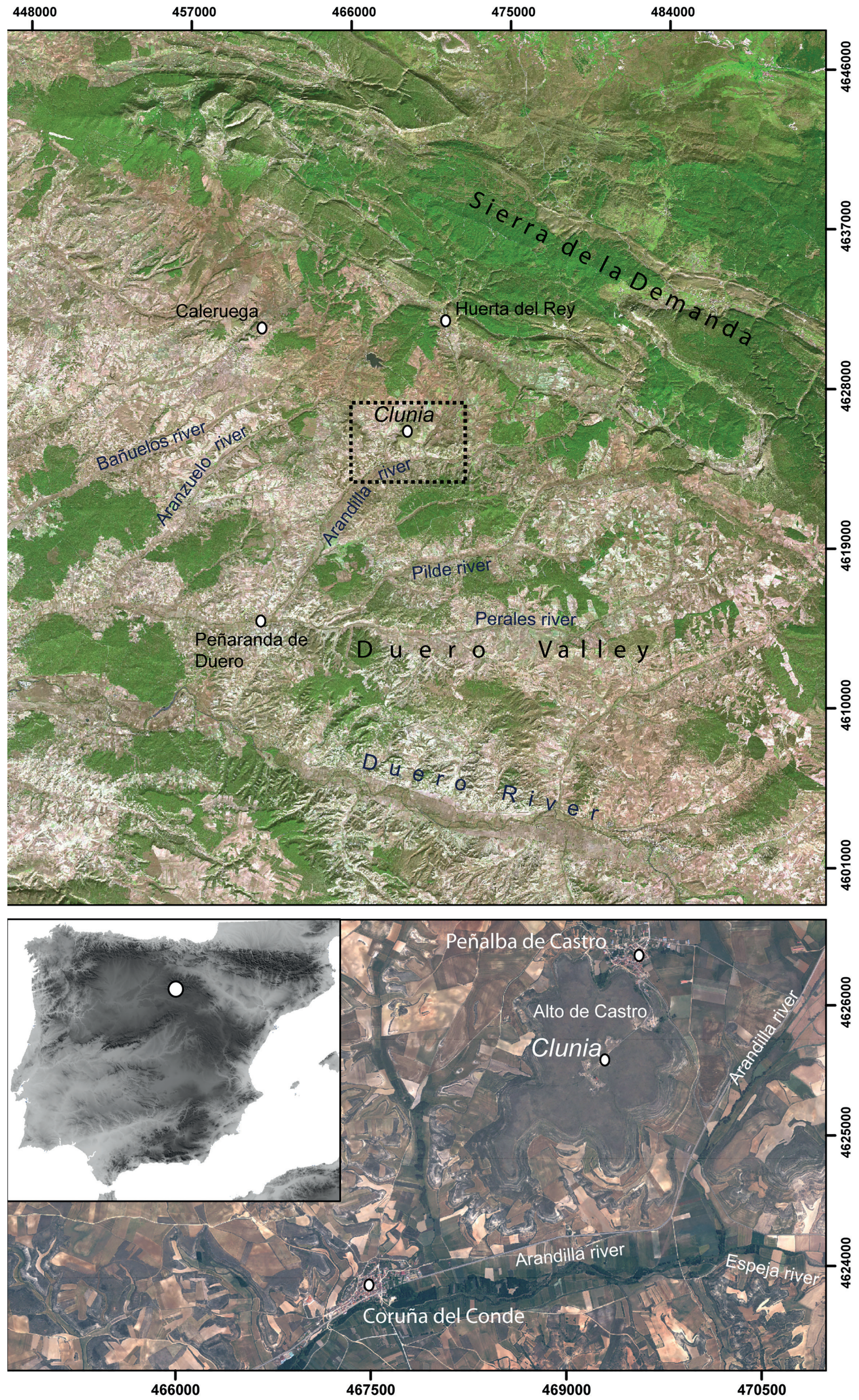

Figure 2. General location of the site: the Duero Valley, and Sierra de la Demanda. Sources: Instituto Geográfico Nacional (IGN), Plan Nacional de Ortofotografía Aérea (PNOA), Maximum resolution $(20 \mathrm{~cm})$. 

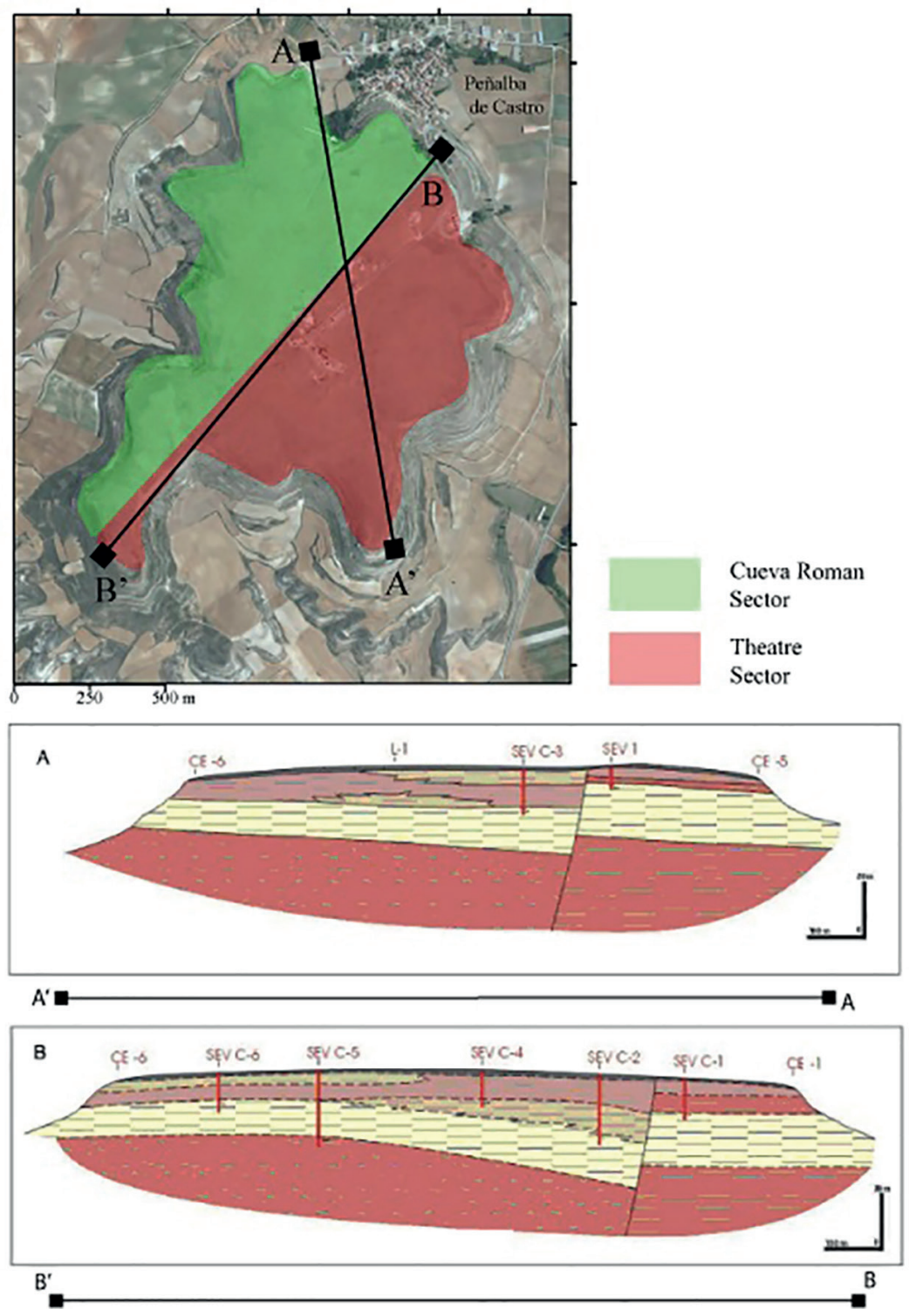

Figure 3. The Valdés and Reina study (2004). The fracture or fault that marks two different hydrological activities. A. Longitudinal Profile. B. Transversal Profile. Sources: Instituto Geográfico Nacional (IGN), Plan Nacional de Ortofotografía Aérea (PNOA), Maximum resolution $(20 \mathrm{~cm})$.

\section{Archaeological Evidence}

Although there were some interventions on the site in the second half of the 19th century, a proper archaeological exploration has not been undertaken until the early years of the following century, with the discovery of the cave called Cueva Román (Hinojal 1913). Shortly after, I. Calvo (1916) carried out the first major work in the city, with excavations in the theatre, the forum, and in the thermal complex called Los Arcos. In 1930 B. Taracena visited the site, and was unable to distinguish any of the buildings that appeared in the description given by J. Loperráez, probably due to the incessant looting of materials carried by local residents from the neighbouring villages.

In 1958, P. Palol took charge of the excavations, giving start to a period of exhaustive work, that continued until 1992 by M. A. De la Iglesia and F. Tuset as directors.
The forum was identified archaeologically in 1960, and its research was completed in 1977 (Palol and Guitart 2000), when the focus of archaeological activity moved on to other areas such as the Cuevas Ciegas sector, where there are some houses with wells and cisterns excavated in the rock (Cuesta 2012b: 193). Near the forum, to the northwest, B. Taracena excavated in 1930 the building that carries his name: Casa Taracena. Additionally, P. Palol initiated a revision of this house, seeking to complete its morphology, and reached to the conclusion that it used to occupy an entire insula. Further east, two thermal complexes are located, called Arcos I and Arcos II, which were explored in the 1980s.

And finally, in 1915-1916, I. Calvo was the first to excavate the theatre. Palol continued the work and noticed that the building was set along the axis of Casa Taracena's main street (De Palol et al. 1991: 
R. Cuesta, I. Fiz, E. Subias, F. Tuset, M. Á. de la Iglesia, Hydraulic and urban management during Roman times based on GIS...

327-329). But a complete excavation has not been carried out until recently (Gutiérrez et al. 2006; De la Iglesia and Tuset 2012).

\section{Cueva Román: the water management of Clunia}

The upwelling of water in these sectors occurs in the area where the limestone and clay come into contact. As already noted, these form the geological structure of the hill. The Romans, who were well aware of the area in which the city was situated, must have located the water upwellings, and used them to gain access to the karst, adapting it to their needs. The internal transformation of the cavity, and the opening of wells for extracting water transformed Cueva Román into a series of cisterns or tanks, which Clunia used for its supplies (Cuesta 2012a: 169-172; 2012b: 153-194). The karst became the great reservoir from which the city was supplied.

As already noted, the filtration or infiltration of rainwater is the essential system for refilling the cave with water. On their descent into the inner levels of the hill, these waters carry a great deal of clay from washing the soil and the descaling involved in the dissolution of limestone. While the system was in
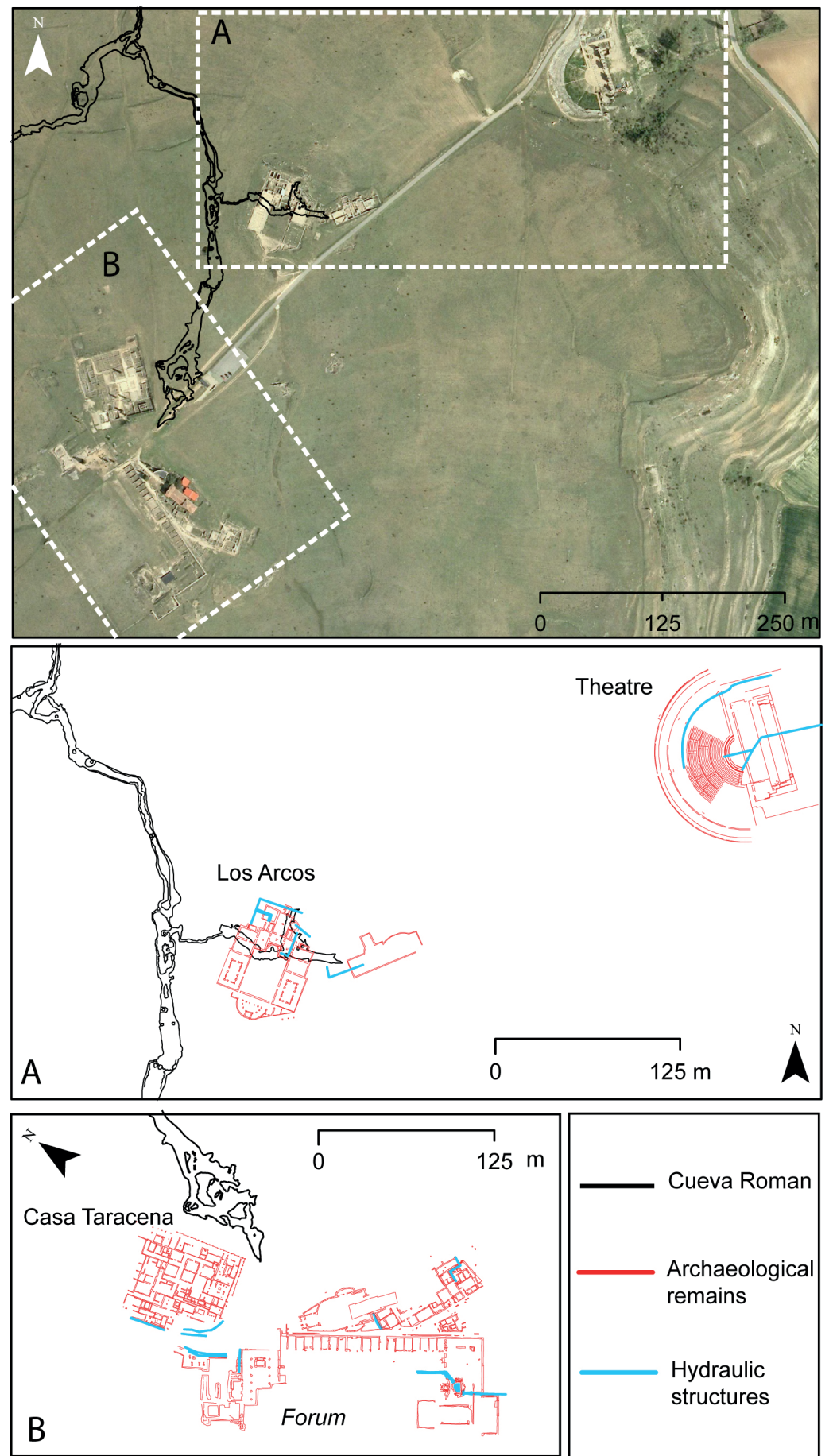

Figure 4. Archaeological and hydraulic structures. A. Los Arcos (I \& II) - Theatre sector. B. Casa Taracena-Forum sector. Sources: Instituto Geográfico Nacional (IGN), Plan Nacional de Ortofotografía Aérea (PNOA), Maximum resolution (20 cm). 
use, its maintenance and care after as an asset of the Roman state contributed for the elements that used to drag the water to remain under control, and they did not cause any problems in the horizontal distribution of water. When the government neglected the system, the natural cycle, in which a new channel pushed the decalcification clays, was re-established. That was how the cave lost the permanent water level that used to enable all the wells in the city to have access to it.

The relationship between the karst cave and the Roman city was first studied by P. Palol, with the collaboration of the Grupo Espeleológico Ribereño (GER), who contributed to the exploration works, subsurface topography, and photography. Thus, it has been possible to determine the relative position of the constructions on the surface with the subterranean galleries and the lagoon. A religious space with inscriptions and figures moulded in the clay has also been discovered (Palol and Vilella 1986). This finding accents the fact that the cave was easily accessible, and even allowed transit.

Also should be taken into account the fact that the Arcos thermal complexes were placed at the vertical side of the karst galleries, so that the access to water was direct and economical (Cuesta 2012b). Most likely, other monuments were related in the same way too, but the galleries have not been fully located yet.

Besides obtaining water from the karst, there is much to explain about how wastewater was carried outside the city. Clunia had to deal with a problem related to this source of water: preventing the underground reservoir from possible contamination by the filtration of wastewaters. Sometimes neglected, it is evident that a drainage analysis of any city must take into account the three basic sanitation and health problems of settlements in the ancient world: wastewaters, rainwater, and surplus water (Crouch 1993: 19-39; Wilson 2000: 151-179).

In result of the archaeological work done by $\mathrm{R}$. Cuesta (Cuesta 2012a), we know that both the public and private buildings had the necessary facilities to organize the evacuation of sewage. Their construction and the items used in that process (formwork, ashlars, opus signinum, etc.) suggest knowledge of the city's underground wealth and the need to avoid contaminating the aquifer. Nevertheless, little is known about Clunia's drainage system and currently, establishing its layout based on the discovered hydraulic remains (Fig. 4) is almost impossible. However, we can assume that it was organized around a primary network, to which another secondary network was added. For this reason, we also decided to study the drainage systems in the city of Clunia as one of the necessary guidelines for determining its urban organization.

\section{Objectives}

In regard of the archaeological data and the special characteristics of Cueva Román as discussed above, this study has the following goals:

- To improve our understanding of the urban organization of Clunia. The various sectors that emerged after half a century of excavation campaigns have revealed an unusual divergence between the city's monuments and buildings in terms of orientation. Given the disproportionate extent of the deposit, and the scarcity of economic resources, we sought to implement a variety of techniques that help understanding the city's urban planning principles.

- To identify the drainage of wastewaters that was possibly used to prevent contamination of the waters from the karst cave.

- To provide an overview of the modern drainage systems in order to study in more detail the forms of urban organization, of which, given the breadth of the field, we currently only have partial knowledge. That is, whether it is possible to identify the organizational structure of a site trough analysing the modern runoff network. The urban organization, which was based on the streets, subdivisions, water channels, and drains, has been partly fossilized in the drainage pathways, although currently conditioned by post-depositional processes.

- The results should provide sufficient elements and indicators to prioritize the future archaeological work on this site.

\section{Materials and Methods}

Geo-archaeology, Remote Sensing, and Hydrological GIS Analysis techniques provide tools for analysing territories, which can be applied in the research of urban planning in cities - particularly in such that have not been in continuous use until modern times. A reading of the orographic forms and moisture differentials is combined with the study of historical cartography, to conduct a new survey of the plateau in order to detect traces of the old city in its different historical contexts. In this research, we have crossed information resulting from different methods, such as several hydrological GIS analysis, functions, and remote sensing. For this we have worked with images from various sensors (SPOT, infrared aerial photographs, geophysical surveys), to which several analysis and enhancing techniques (NDVI, PCA) were applied. Below, follow description of each of these:

\section{Digital Elevation Model (DEM)}

All GIS procedures described herein require a DEM as input. In this research, we first used a DEM produced by the CNIG (Centro Nacional de Información Geográfica) with a resolution of $5 \mathrm{~m} /$ pixel. This DEM was constructed by extracting it from aerial flights by the PNOA (Plan Nacional de Ortofotografía Aérea) using photogrammetric functions. However, the same Institution has produced a LiDAR coverage for Spain, and also a DEM at a resolution of 5 metres/pixel, and recently published this data. Our project has also used this second data source, repeating the processes described herein.

\section{GIS Drainage Analysis}

Using GIS applications, we were therefore able to calculate tree-like drainage networks, or Local Drainage Direction maps (LDD). Using the LDD map generated, we established the foundations for the 
study of the city's drainage courses, and determined their order based on their different capacities. We also tried to distinguish between the primary and secondary networks, as well as seek for the elements that would have made circulation impossible, or such that would have facilitated it. LDD maps may also be used to provide additional information about a region's hydrology and landscape morphology, as reported by Connolly and Lake (2006: 257).

As a result, we generated LDD maps using the appropriate functions (Flow Direction, Flow Accumulation, etc.) of GIS software like ARGIS 10.0 or SAGA (System for Automated Geoscientific Analyses). We then processed and removed the segments that were not expressive or representative for this study, and calculated the flow threshold (Olaya 2004b: 123129). The GIS functions enabled us to establish the order of the traces, and to determine which of them were part of the primary network, and which were part of the secondary.

\section{Wetness Analysis}

In addition to the improved flow calculation functions (e.g. Catchment Area) provided by GIS, there are also other applications, such as the TWI (Topographic Wetness Index; Böhner et al. 2002), and the SWI (SAGA Wetness Index; Boehner et al. 2002). Both of these indexes, the former in particular, have provided some very interesting results.

The usefulness of the TWI lies in its ability to express the relationship between the morphology of the terrain and the accumulation of water in the soil, which is in turn responsible for the shape outline of the runoff water, its flow rate, etc. This index enables us to calculate the production of runoff water when the soil is saturated, at which point the water level reaches the surface. The initial concept behind this parameter is to focus on identifying areas that behave similarly from hydrological point of view, providing an identical response in terms of precipitation/runoff (Olaya 2004: 107-108), as well as an estimate of the predicted water accumulation in a certain area. This index has rarely been used in scientific publications related to archaeology.

The SAGA Wetness Index (SWI) is based on a modified catchment area calculation, which does not consider the flow as very thin film. As a result, it predicts a more realistic, higher potential soil moisture, as compared to the standard TWI calculation for cells situated on valley floors with a small vertical distance to a channel (Moore et al. 1991; 1993; Olaya and Conrad 2009: 304). Some studies, such as those by Vogel and Märker (2010), have applied SWI to ancient landscape. Their research was based on the reconstruction of the Sarno River paleo landscape in Italy before the eruption of the Somma-Vesuvius volcanic complex in $79 \mathrm{AD}$. The SWI was used as one of the 15 topographic indices applied in the development of a predictive model, which reconstructed the landscape prior to the volcanic eruption.

Bock et al. (2009: 153) proposed a modification of the SWI that is derived by weighing (multiplying) the slope angle within the calculation of the index.
This modification, known as the mSWI, provided a greater amount of details. The study carried out by these authors applied the index to a number of details, such as Holocene and Pleistocene flood plains and terraces, in contrast to Pleistocene moraines and sandy outwash planes. Another advantage is the increased contrast between river flood plains.

\section{Other GIS functions}

In order to highlight the micro-topography, we applied a shadow analysis (Hillshade). This function allows the application of a weight to the DEM's height, which further emphasizes the relief. This calculation shows aspects of micro-topography, such as pits or elevations that would otherwise be difficult to observe in the field. This initial study was also necessary due to the heavy fragmentation of the entire hill, as seen in USAAF's (United States Aerial Army Forces) flights of 1956-1957, until the site was turned into an archaeological park. The abandonment of crop cultivation turned the hill into wild grazing land, and therefore increased the difficulty in regards of visibility.

GIS functions were also applied to generate topographic profiles. These profiles allow us to analyse in detail the topography, detect and measure shapes that could identify streets or buildings.

\section{Lidar Visualization Tools}

Digital elevation models are raster datasets containing elevation values. Because these numerical datasets are not readable as such, visualisation techniques are necessary to convert the DEM into human-readable greyscale or colour images. The obvious use of different visualizations is for visual examination of data. Some visualization techniques (Kokalj, Hesse 2017: 13-16) produce results that can be related to physical quantities (e.g. sky-view factor - SVF, and local relief model - LRM), while others only have a presentational value (e.g. principal components of hillshading from multiple directions).

These techniques have been applied in the last years on DEM obtained using LiDAR, and provided results of great interest as in the case of Torre Cisterna in Basilicata (Masini et al. 2018), Roman military enclosures in the Galician landscape (Costa Garcia et al. 2016a; Costa Garcia et al. 2016a). In all of them, visualization technics allow the highlight of archaeological structures. In this case, we used the Freeware program Relief Visualization Toolbox (Stular et al. 2012).

\section{Remote Sensing Analysis}

This part of our study was conducted in one area of the site - between the theatre and Cuevas Ciegas. This sector is one of the extensive areas in the archaeological site where no previous archaeological interventions have taken place, but where dispersed architectural and ceramic materials have been found. Its surface area is approximately 7.3 hectares. This area is also the highest of the entire site, with a maximum altitude of 1020.70 MAMSL. Therefore, the motivation to analyse in detail this sector focuses 


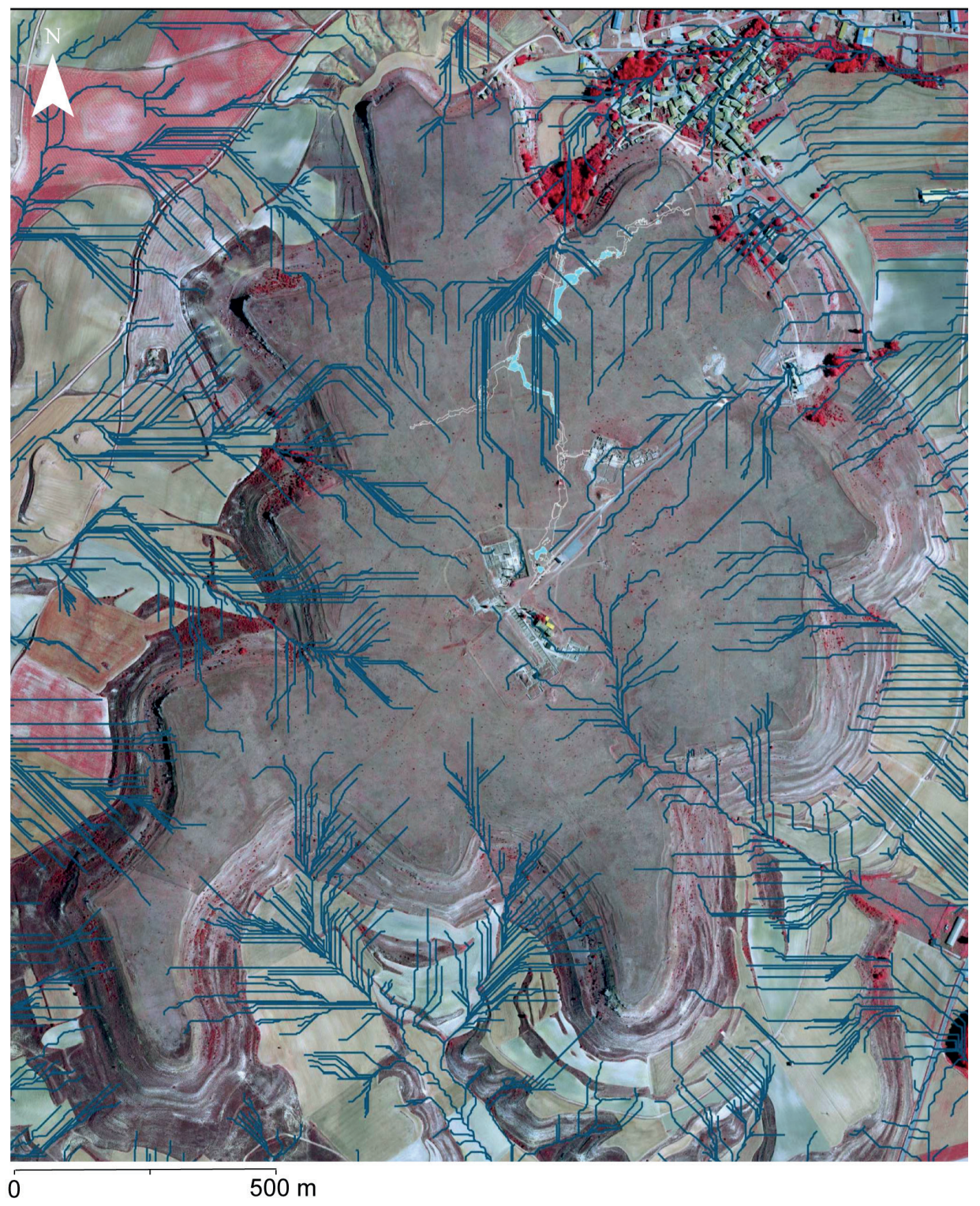

Figure 5. Results of the LDD map, using the Flow Accumulation function of ArcGIS 10. This data is not yet classified in the main and secondary drainage networks. Sources: Plan Nacional de Ortofotografía Aérea (PNOA), NIR image 2009.

on obtaining a better knowledge of an area that has already been signalled about by Loperraez, but had not been archaeologically excavated.

In this section, dedicated to the detection of traces of structures not visible on the surface, we used different data sources

- NIR \& RGB band images from PNOA aerial photographs (dating from 2011, 2009, 2007, and 2005). Unfortunately, the PNOA flights over the Clunia area took place between June and August. In order for NIR images to provide archaeologically positive results, the scenes must be captured in seasonal wet periods, or such favourable to the growth of vegetation, such as spring, or autumn (Dabas et al. 2006: 116-117). For this reason, only one of the PNOA images, dating from 2007, could provide interesting data for our work.

- The aerial photographs obtained from the USAAF flight of 1956 were rectified by photogrammetric techniques at the Instituto Geográfico Nacional (IGN).

- A varied series of SPOT pictures (from 2005 to 2011), were obtained from the IGN ldata server. These were corrected applying the Gram-Schmidt Spectral Sharpening Method, using the corresponding panchromatic image, and obtaining a 4-band multispectral image with $10 \mathrm{~m} /$ pixel resolution. Several projects have used multispectral SPOT images when locating archaeological sites (Fowler 1993; 1995), and as a result, multispectral SPOT scenes taken between 2005 and 2011 were also used. The expectations for the sequence of images captured over six years were no better than of those from the PNOA. The catalogue of SPOT scenes in the IGN was also captured in seasons when the conditions for remote sensing analysis were not suitable. However, on this occasion two scenes delivered interesting results to compare with 
R. Cuesta, I. Fiz, E. Subias, F. Tuset, M. Á. de la Iglesia, Hydraulic and urban management during Roman times based on GIS...

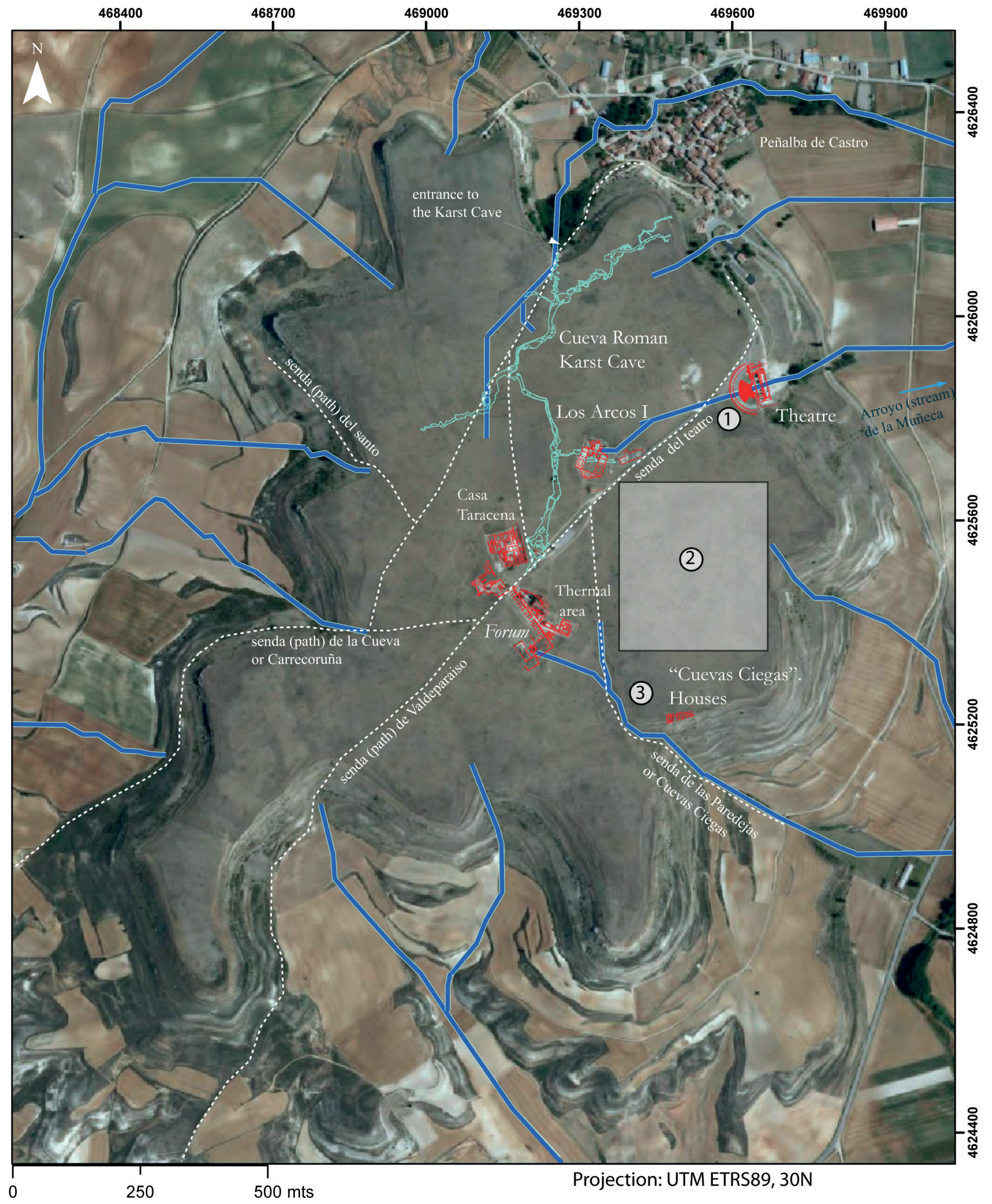

Figure 6. View image of the hill with the archaeological remains excavated. Main drainage network calculated on the hill, showing the areas referred to in the text. 1. Theatre area. 2. Area between the Theatre and Cuevas Ciegas. 3. Access to Cuevas Ciegas and Senda de las Paredejas. ETRS89, 30N projection. Sources: Instituto Geográfico Nacional (IGN), National Plan of Aerial Orto-photography (PNOA), Maximal resolution $(20 \mathrm{~cm})$. 
the other data. These were from 2007 and 2008, (09/28 and 06/18), respectively.

Additionally, several enhancing spectral functions have been used as well. For example NDVI and TDNVI functions were applied to highlight the presence of building elements (walls) or negative items (septic tanks, wells, and reservoirs). NDVI is therefore an analytical technique that compares the IR and $\mathrm{R}$ bands based on multispectral images (Merola et al. 2006; Rowlands and Sarris 2007). The presence of these structures implies a higher or lower level and decomposition of organic components that retain humidity to a greater or lesser extent, and therefore highlights their existence by means of changes in the density of vegetation (Parcak 2009: 92-94).

Later we eliminated the redundancy in the electromagnetic spectrum of a multispectral scene by applying a method known as Principal Component Analysis (PCA), the synthesis capacity of which makes it a very useful technique for filtering images prior to other multispectral analyses. Its application in archaeology has led to the detection of sites (Stafford et al. 1992), buried walls (Garbuzov, 2003), and archaeological anomalies in images from the IKONOS sensor. Our working group applied this method in the research and detection of traces of flood channels in the Middle Nile Valley (Fiz, Subías and Cuesta 2012; Subías and Fiz 2011; Subías, Fiz and Cuesta 2012).

Finally, the SPOT scenes and the results of the spectral functions were subsequently enhanced using adaptive filters (Lee 1980). All the spectral analysis and operations were performed with ERDAS Imagine 10 software.

\section{Geophysical surveys}

At the same time, a series of geophysical surveys were carried out by the SOT-Prospecció Arqueològica Company. These surveys were completed in another area of the site, in order to find the wells that provided access to Cueva Román.

The initial analysis of the results obtained from observation of the micro-topography and the treatment of the NIR images from the PNOA led to the decision to order the above-mentioned company a geophysical survey.

For this survey was applied electromagnetic technique, using the Grad601 fluxgate gradiometer manufactured by the Bartington company, in a very specific sector of the area chosen for our study. The survey was carried out on a sequence of three grids measuring $20 \times 20$ metres on each side, each with N-S orientation, thus forming a total area of $20 \times$ 60 metres.

\section{Results}

\section{GIS drainage analysis}

We found an extensive network (Fig. 5) that included the natural drains through which rainwater flowed by means of gravity, as there was no obstacle in its path; and traces that are fossilized sections of the ancient city of Clunia. We believe that the primary drainage network (Fig. 6) is the widest and is connected to the main axis of the city and its access points and transit routes. The secondary network includes all the minor channels from buildings that are connected to
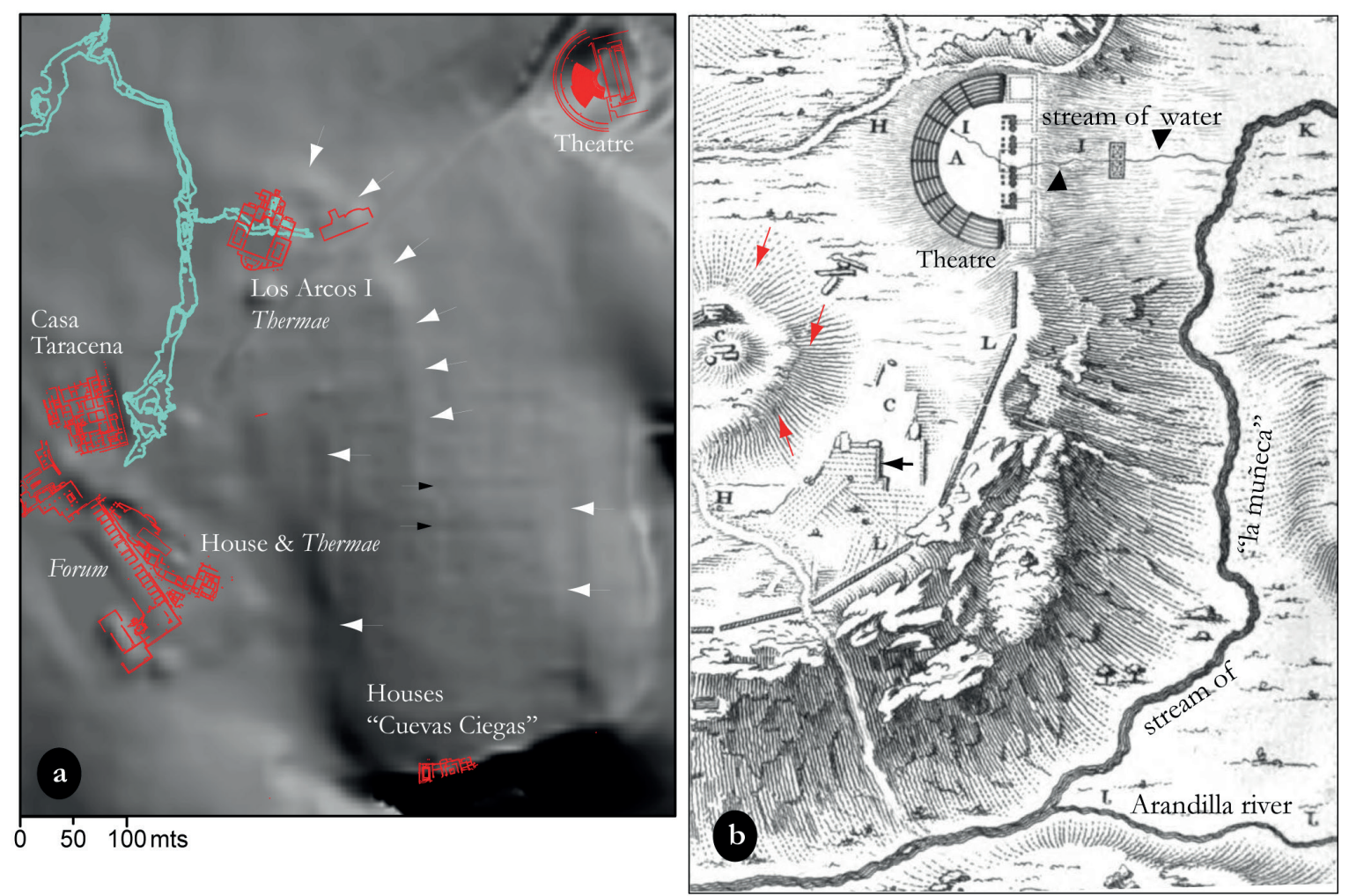

Figure 7. a. Hillshade result, main drains. Sources: LIDAR-DEM (5 m/pixel), Plan Nacional de Ortofotografía Aérea (PNOA); b. Detail from the Loperráez plan. 
R. Cuesta, I. Fiz, E. Subias, F. Tuset, M. Á. de la Iglesia, Hydraulic and urban management during Roman times based on GIS...
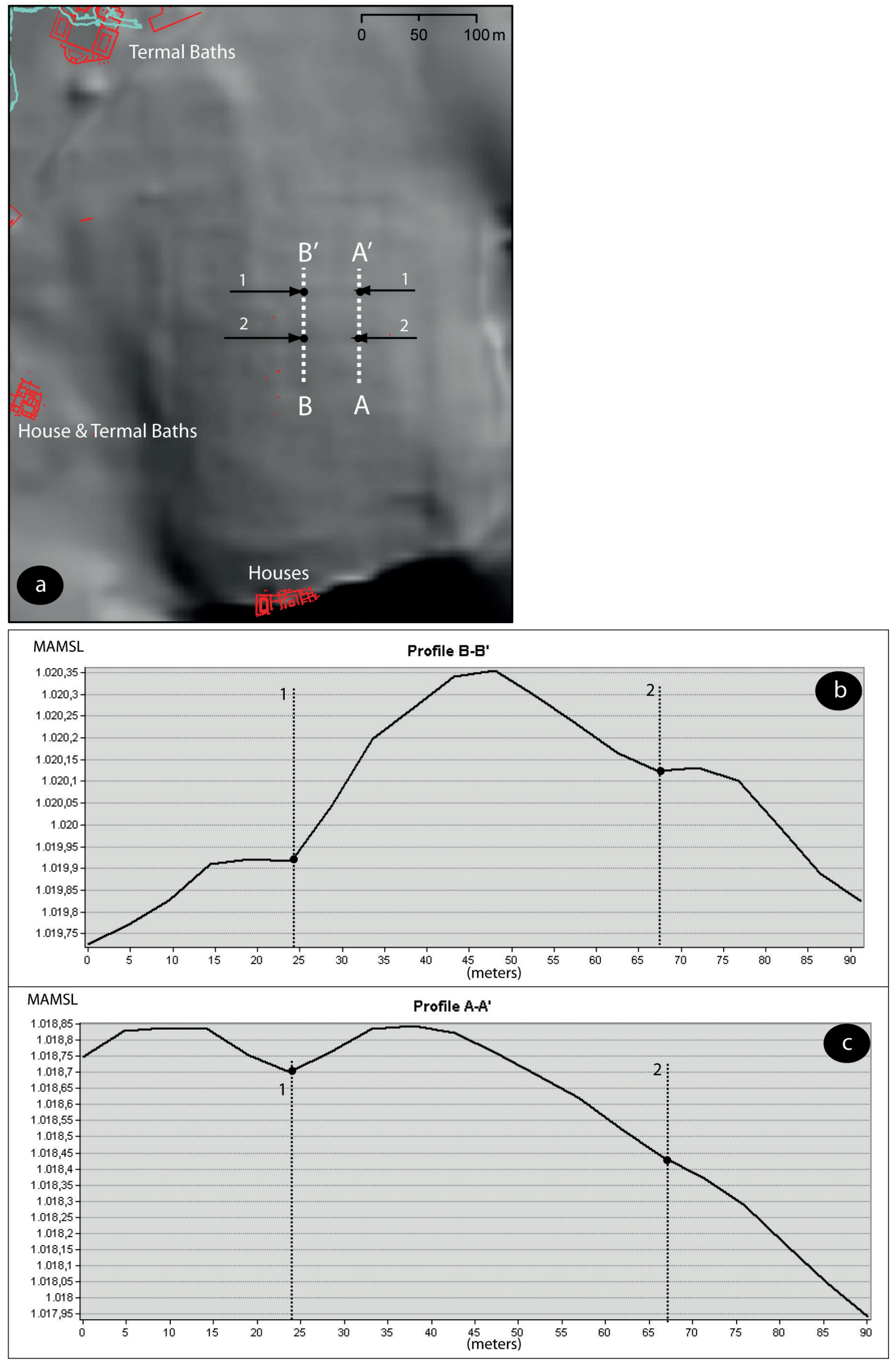

Figure 8. Topographic cross-sections. a) Location of the cross section; b) Profile of section B-B'; c) Profile of section A-A'. 
the primary network, or to the streets where excess waters from fountains and cisterns used to run. The first image obtained reflected the overlap between the drainage channels or points, and the access roads to the city we know of today: Senda del Santo or Vía Militar, Senda de la Cueva or Carrecoruña, Senda de Valparaíso, the access to Cuevas Ciegas or Senda de Las Paredejas, and Camino del Teatro. Among all the drainage branches highlighted by the raster map, there are three, that we believe could be parts of a possible primary network: first, the Los Arcos-Theatre axis, which descended eastwards across the centre of the theatre and went on until reaching the stream of La Muñeca (Thermae-Theatre); second - the drain running from the forum and taking advantage of the slope towards Cuevas Ciegas (Forum-Paredejas-Cuevas Ciegas); and finally, the drain from Casa Taracena, which rises in the Cueva Román area (Casa Taracena-Cueva Román).

The drains in the north-northeast and the theatre areas flow into the stream of La Muñeca, and its waters passed through the Pedregales area and into the Arandilla river. This "stream of water" could be the same as the one drawn by J. Loperráez, which came from the spring of cavea media, crossed the orchestra and stage, and exited through the Valva Regia until it reached the Arandilla river, although its position in this drawing suggests it was closer to the stream mentioned above (Figure 6, label 1; Figure 7, label b).

To the east-southeast of the hill, we found two areas clearly marked as suitable for the transit of drains. The first was between the theatre and Cuevas Ciegas. In this case, the drains started in an unexcavated area where aerial photos and high-resolution DEM revealed a number of traces (Figure 6, label 2). The second area in the southeast was the access to Cuevas Ciegas and Senda de Las Paredejas. In this area, the drains flowed from both sides of the slope, meeting in a central drain with the runoff and drainage from House n. 3-Forum-Thermae area, the Forum area and the Cuevas Ciegas houses, following the path of the cardo (east-southeast), as shown by the excavations on the eastern part of the forum. The drain could have followed the road until it left the city, and from there taken advantage of the slope and the natural de-elevations in the landscape (Fig. 6, label 3).

\section{Other GIS functions}

Broadly speaking, the simple application of the Hillshade function to the DEM highlighted two significant elements in the landscape. First, we can see an oval shape that was already shown on the map by Juan Loperráez Corvalan (Figure 7, label b). Second, there is a rectangular shape associated with a possible regular system of plots, some of which have remained fossilized in the separations of fields that were in use in the years prior to the approval of policies to protect the site.

A study of the topographic profiles applied to this area using DEM showed that the micro-topography is a sequence of elevations interrupted by brief flat areas. Both create spaces, which are distances of
10, and 30-35 metres correspondingly, despite being conditioned by the DEM pixel dimension.

Furthermore, continuing the topographic profiles the narrower flat spaces form a concavity, which matches the results obtained in the calculation of the drainage network in this area (Figure 8, label 1 and label 2). For greater accuracy, the Catchment Area Function implemented in SAGA using the Kinematic Routing Algorithm (KRA) (Lea 1992) was calculated in this case. As we shall see in the next section, the result was the detection in this area of four E-W oriented drains, some of which were intersected by others with NE-SW orientation.

\section{Wetness Analysis}

In this study we have applied the TWI, SWI, and mSWI indexes, which enabled a classification based on the relationship between runoff and land morphology. The result of the TWI (Fig. 9, labels 1 and 2) provides more information than that obtained by calculating the Flow Accumulation, or its SAGA function variant, the Catchment area. The D-Infinite was used as the execution algorithm for its calculation. As mentioned above, this corrects the inaccuracy of the D8 and delivers more realistic results. In the study area, five horizontal traces corresponding to high values of the index are visible, and these therefore follow a slope and a layout that encourages the flow of water.

The SWI analysis (Fig. 9, labels 3 and 4) from this perspective provides additional significant information. As stated above, this index should predict the areas that behave as hygrometric differentiation factors or damp marks. If so, this index obtained from high resolution DEM would help to detect hidden archaeological features in the topography of the landscape. However, the result does not make a sufficient distinction in order to be able to clearly distinguish the traces hinted at in the DEM, unless the mSWI is applied (Fig. 9, labels 5 and 6).

\section{LiDAR Visualization tools}

The results in this case are of great interest since they verify the forms views with the application of the Hillshade function. In this case, they are the SVF functions (Sky View Factor) and Openness Positive, which give positive results clearly, indicating an organized structuring of the study area, and confirming this N-S orientation (Fig. 10).

\section{Remote Sensing Analysis}

The PNOA 2007 flight NIR image shows an oval colour differentiation, similar to the one observed in the results of the DEM's Hillshade function. This differentiation is manifested through humidity differentials (Fig. 11, label a).

The plot boundaries and paths still visible on the 1956 USAAF flight have also been registered with GIS drawn tools (Fig. 11, label b). The result was added to the GIS with the aim to compare it with the traces detected in the geophysical survey, remote sensing images, LDD maps, and the Wetness Index results. 
R. Cuesta, I. Fiz, E. Subias, F. Tuset, M. Á. de la Iglesia, Hydraulic and urban management during Roman times based on GIS..
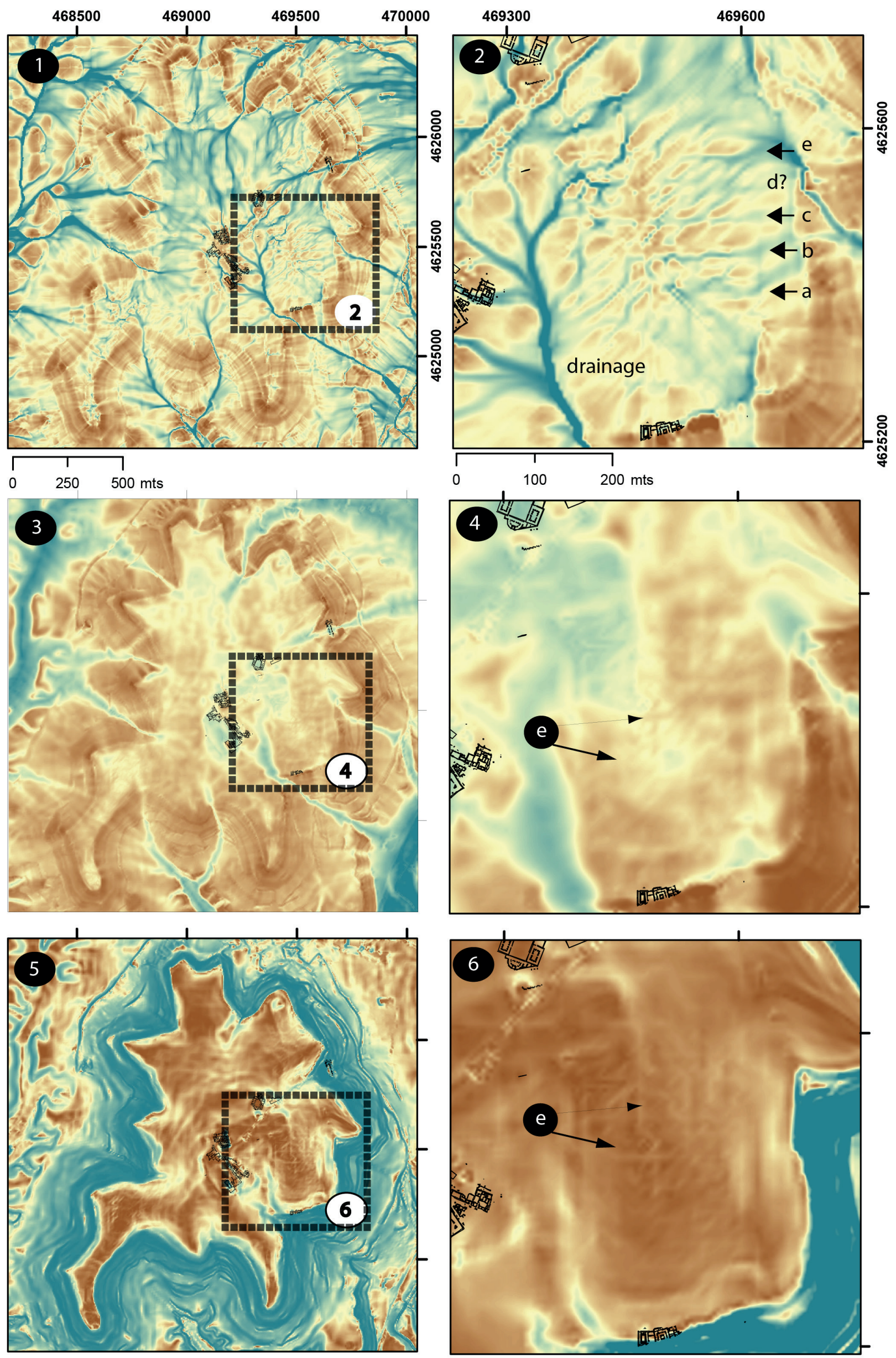

Figure 9. Wetness analysis: results. 1) Topographic Wetness Index. 2) Topographic Wetness Index. Detail of work area. 3) SAGA Wetness Index. 4) SAGA Wetness Index Detail of the work area. 5) Modified SAGA Wetness Index. 6) Modified SAGA Wetness Index. Detail of the work area. Sources: LIDAR-DEM (5m/pixel), Plan Nacional de Ortofotografía Aérea (PNOA). 
R. Cuesta, I. Fiz, E. Subias, F. Tuset, M. Á. de la Iglesia, Hydraulic and urban management during Roman times based on GIS...

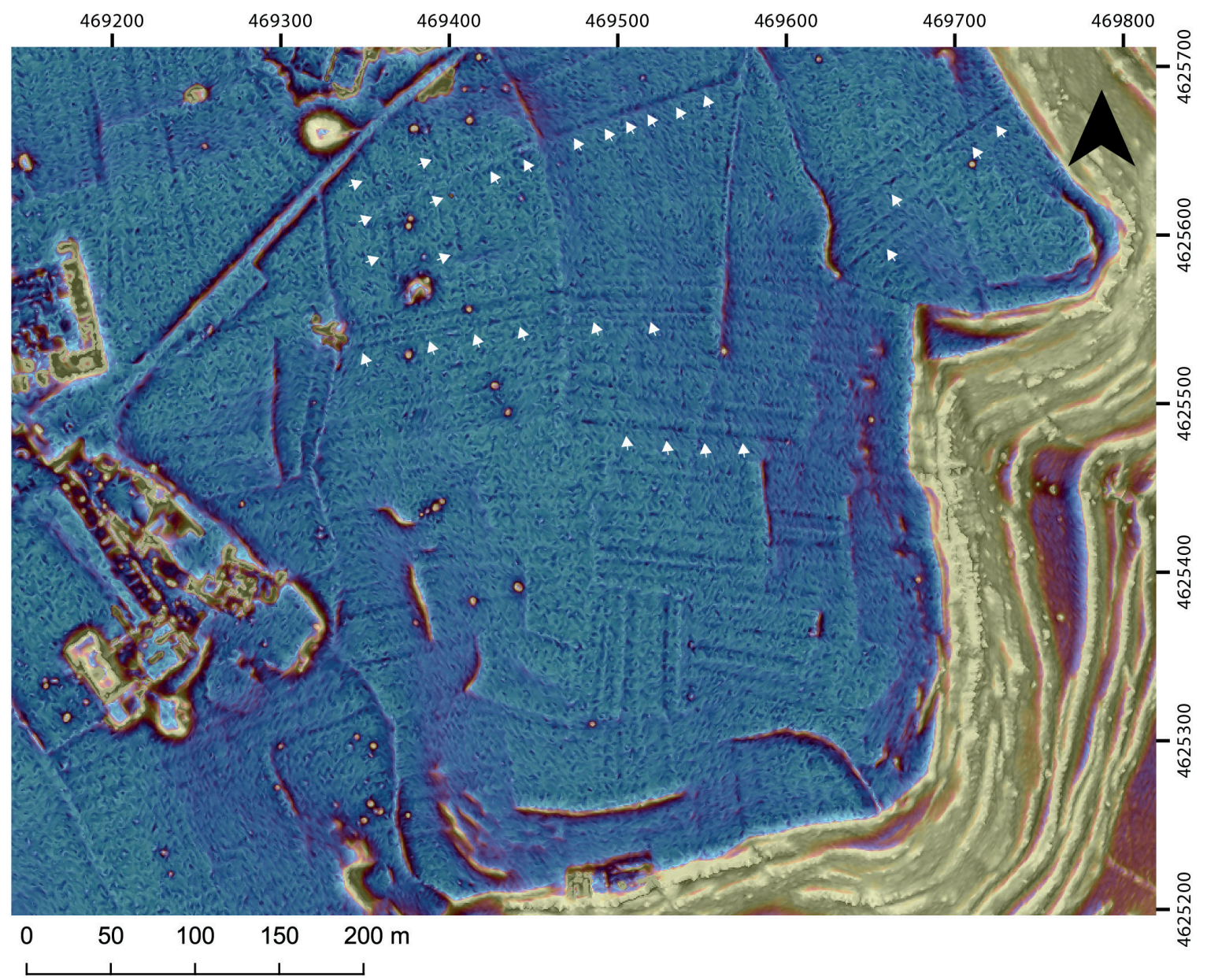

Figure 10. Results of the SVF function application.

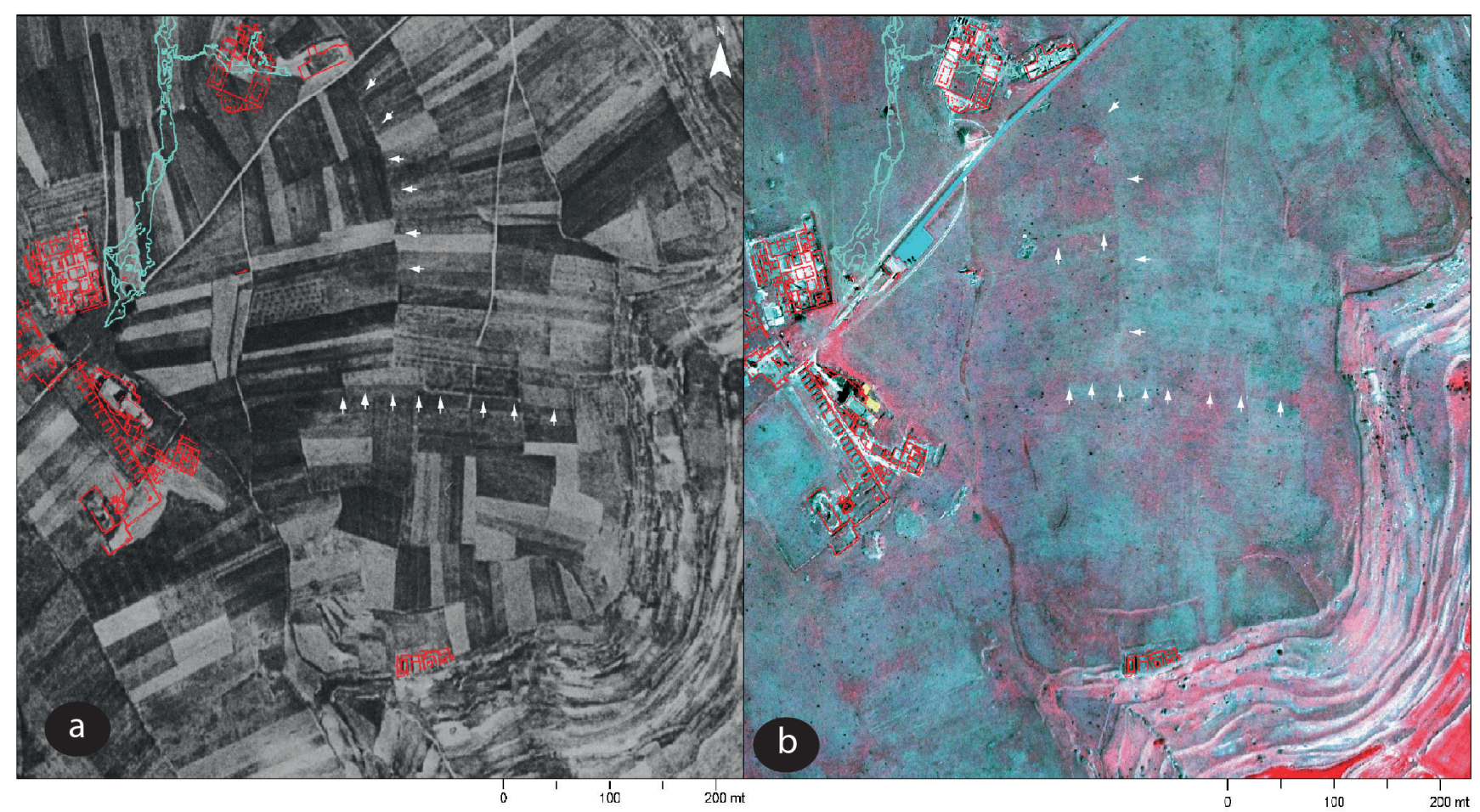

Figure 11. Source: Plan Nacional de Ortofotografía Aérea (PNOA), NIR image, 2007. The dampness differentials reveal the same oval and rectangular shapes that can be seen on Figure 7, label a. 

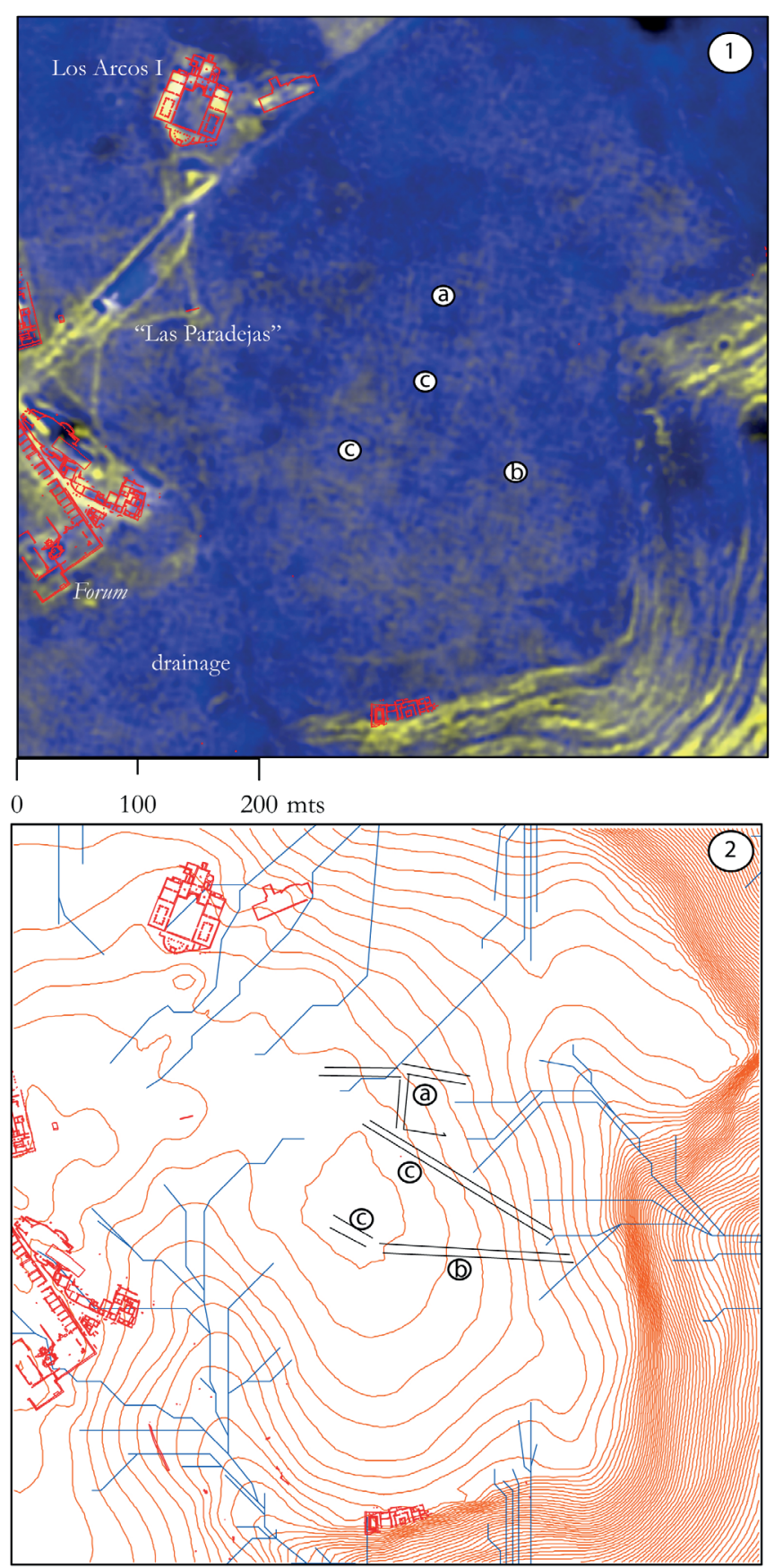

Figure 12. a) SPOT 2007 PCA results $1 / 1 / 1$ bands; b) Interpretation of secondary traces and drains.

Moreover, after receiving various treatments and filter analysis, the SPOT image data were superimposed with the rest information on the GIS ARGIS 10.0. The expectations for the sequence of images captured over six years were not better than those from the PNOA. The catalogue of SPOT scenes in the IGN was also captured in seasons when the conditions for remote sensing analysis are unfavourable. However, on this occasion two pictures provided interesting results to compare with the other information. These were from 09/28/2007, and 06/18/2008, respectively. The most prominent anomalies were also drawn.

The 2007 SPOT image thus presents anomalies (Fig. 12 , labels $\mathrm{a}$ and $\mathrm{b}$ ) with N-S orientation, previously observed in the Hillshade, in the drainage network, in the geophysical survey, and, as will be seen below, in the wetness index calculation. The other orientation observed (Fig. 12, label c), NE/SW is in long parallel lines, and these are also the same as the anomalies found in the geophysical surveys.

The 2008 SPOT image nevertheless shows some abnormalities that basically do not match those observed in the scene captured a year earlier. However, the validity as regards to urban organisation is shown by the fact that they follow the same orientation as the thermal sites of Los Arcos I and the Forum House (Fig. 13, label a). Another abnormality observed (Fig. 13 , label b) is an orientation like the Paredejas site, which has been identified as a possible public building. This anomaly coincides with the beginning of one of the secondary drains and one of the excavated streets adjacent to the Taracena house. A comparison of this information with the 1956 flight pictures shows that it coincides with one of the boundaries of cultivation.

\section{Geophysical surveys}

A comparison of these anomalies with the shapes of walls and buildings analysed by the Fluxgate gradiometer shows that there is a series of structures oriented $\mathrm{N}-\mathrm{S}$ and E-S that are approximately located on either side of one of the traces observed in the SPOT 2007 scene (Fig. 14, label a). This latter anomaly comprises two darker parallel alignments, and has a width of approximately 7 metres (a street, perhaps?). They also match some of the drains with E-W orientation, and some of the excavated archaeological structures. The southern end of the geophysical survey shows other anomalies, oriented NE/SW, matching one of the traces detected in the 2007 SPOT scene that goes straight towards these structures (Fig. 14, label b).

Finally, the set of anomalies detected using different methods match in terms of their position and orientation with the set of structural features drawn by Loperráez in the $18^{\text {th }}$ century. It should be noted that none of them belongs to the plot structure of the hill recorded in the photograph taken by the 1956 USAAF flight.

\section{Discussion}

\section{The drainage system}

This first image of the flows distribution and accumulation shows the existence of three primary networks with paths that do not entirely match the assumed direction of the main streets. We must remember that neither the Cloaca Maxima in Rome, nor the cuniculus in Tarragona, for example, do this (Mar and Ruiz de Arbulo 2011: 269-271). The underground channels in these cases were responsible for draining the areas of the city that were most vulnerable to floods and heavy rains. These branches that could have been the "primary network" draining the city of Clunia would have followed the layout of the land in relation to the points where the circulation of natural drainage was observed, and from there, would have been channelled so as to prevent damage to buildings. Only future excavations will allow us to determine 

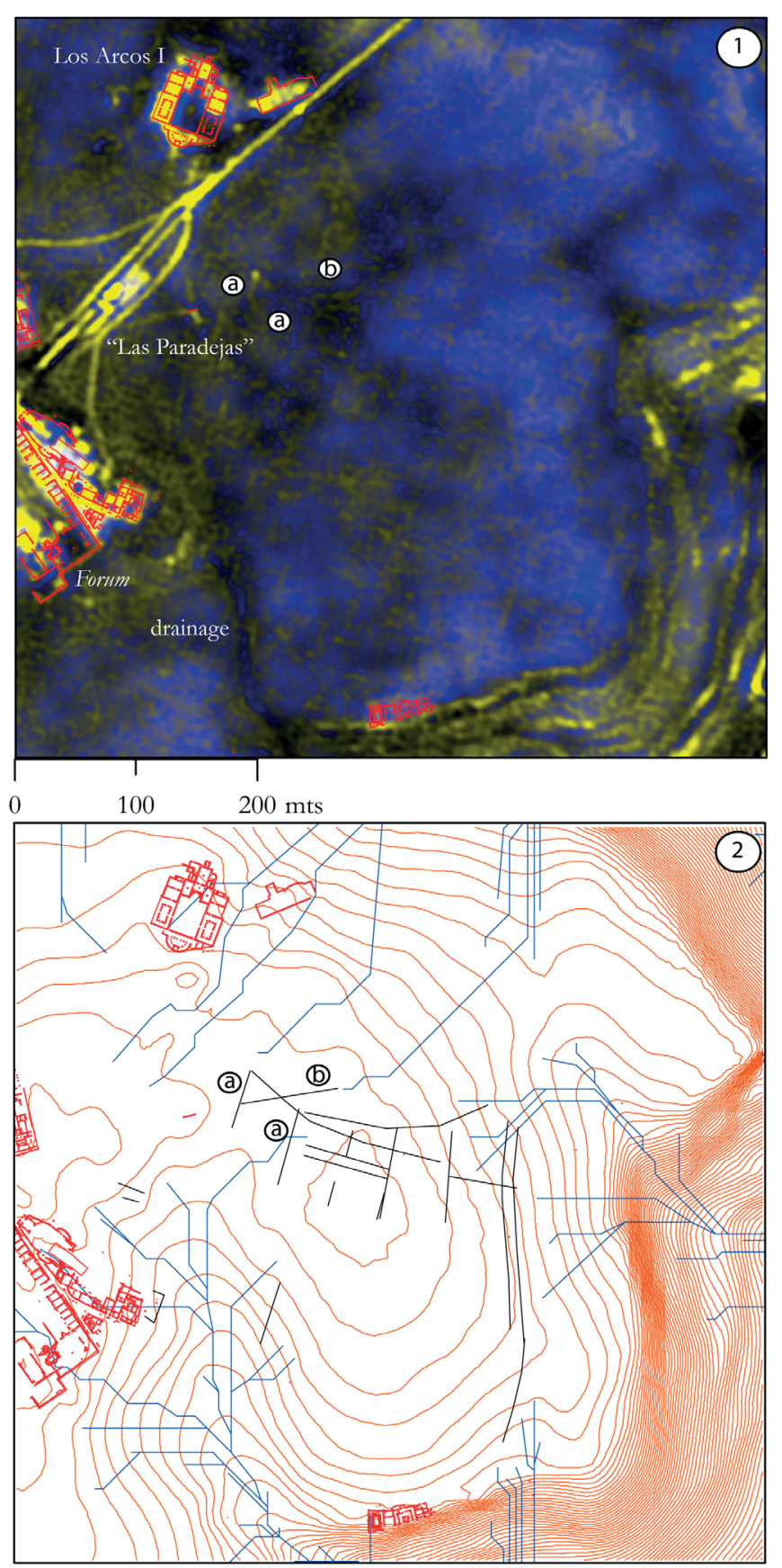

Figure 13. a) SPOT 2008. PCA 1-1-2 bands; b) Interpretation of secondary traces and drains.

their characteristics, i.e. whether they were open-air drains or underground channels.

The drains located in the theatre coincided with the upwelling of water in the north and south parascaenium, and with the building's central drainage (underground channels), in its descent to the Arroyo de la Muñeca (Fig. 15, label B). Some of these buildings' features overlapped the drainage lines on the raster map to some extent. When considering the underground channels, we need to bear in mind that the overlap was due to the fact that the calculation performed by the program follows the natural direction of the land, as the channel is not visible on the surface. Another overlap is located in the southern aditus drain conduit, which was an attempt to solve problems of water leakages in the area around the year $169 \mathrm{AD}$, during the refurbishment of the theatre. The conduit of the cavea, and the northern parascaenium excavated by P. de Palol, did not overlap the drainage traces on the raster map at any point. All these points overlap with what we believe to be the possible primary network, which reached the theatre from the Los Arcos I and II areas. However, the channels and drains in the bath area did not overlap the "flow distribution and accumulation" drainage lines. Due to their direction and gradient, they could be considered part of the secondary network that linked the buildings with a main collector (perhaps in the drainage direction shown by the raster map), or drained directly into the street, which could have had a central channel (like the streets of Tiermes), or a side channel (as in Pompeii), along which the water from the fountains or rains flowed. Similarly, the drain located at the top of the theatre could have been part of a road providing access to the theatre from the centre of the city, via the thermae.

If channels and sewers took advantage of the land's natural gradient to facilitate the flow of water, this should be taken into account when studying the relationship between the results obtained with the production of the "distribution and flow accumulation raster map", and the channels which we known in result of excavation works.

We will now focus briefly on the channels and drains in the forum area. They all follow a path across the branch highlighted on the raster map (Fig. 15, label A). As in the case of the Los Arcos, the known features in the Forum-Paredejas-Cuevas Ciegas area were part of a secondary network, which appears to have run from the buildings to the streets alongside them (cardo). However, in the forum square, the layout of the primary trace on the raster map appears to correspond more to the channel of the line of the forum's double portico (which collected water from the eaves of the roof), and there is a branch which to the east coincides with the tank/nymphaeum and the forum's drain. Both suggest the existence of another tank of this type to the west, as seen in other forums such as those at Merida, Empúries, Valeria, and Évora (Álvarez Martínez \& Nogales Basarrate 2004: 308-309; Cuesta 2012b: 271).

\section{New data on the urban structure of Clunia}

The analysis of DEM's Hillshade showed two items that attracted our attention: the existence of a roughly circular enclosure, which contained all the buildings that constitute the nerve centre of the city (except the theatre and the Cuevas Ciegas houses); and a rectangular enclosure, located in the southeast quadrant of the hill and continuing to the Cuevas Ciegas area, where horizontal and vertical traces with a clear north-south and east-west orientation were visible.

Likewise, the results of the wetness analysis showed five visible horizontal traces corresponding to high values from the index. One of these (Fig. 8b, label b) matches one of the alignments observed in the 2007 
R. Cuesta, I. Fiz, E. Subias, F. Tuset, M. Á. de la Iglesia, Hydraulic and urban management during Roman times based on GIS...

SPOT image. However, considering the problems of the various algorithms, which calculate the Flow Accumulation function, is needed. For instance, ARCGIS functions such as Flow Direction, and its derivative Flow Accumulation, use the D8 algorithm (O'Callaghan and Mark 1984), which is the most implemented in all the applications, but is also the most often subject to problems arising from simplification when choosing the runoff flow direction (Olaya 2004b: 61-76). For the same reason, we applied more reliable methods such as FD8 (Freeman 1991), D-Infinity (Tarboton 1997), and DEMON (Costa-Cabral and Burges 1994), which are focused on correcting the faults of D8, and adapting them to more realistic conditions. These functions are implemented in other GIS, such as open source, including SAGA (Olaya 2004a; Böhner, McCloy and Strobl 2006).

Moreover, the study of the sections made in the same area allowed observing the appearance of flat areas with a width of 10 meters, and separated from each other by 30-35 meters, despite being conditioned by the DEM pixel dimension. This last modulation reflects the possible urban planning measures that were common in Roman times $(1$ actus $=35.4$ metres) but there are reasons for approaching this data with some degree of caution. First, there is the resolution of the DEM itself - 5 metres, and second, the algorithm of the flow direction calculation, an aforementioned problem. However, the application of the LiDAR data visualization functions contribute
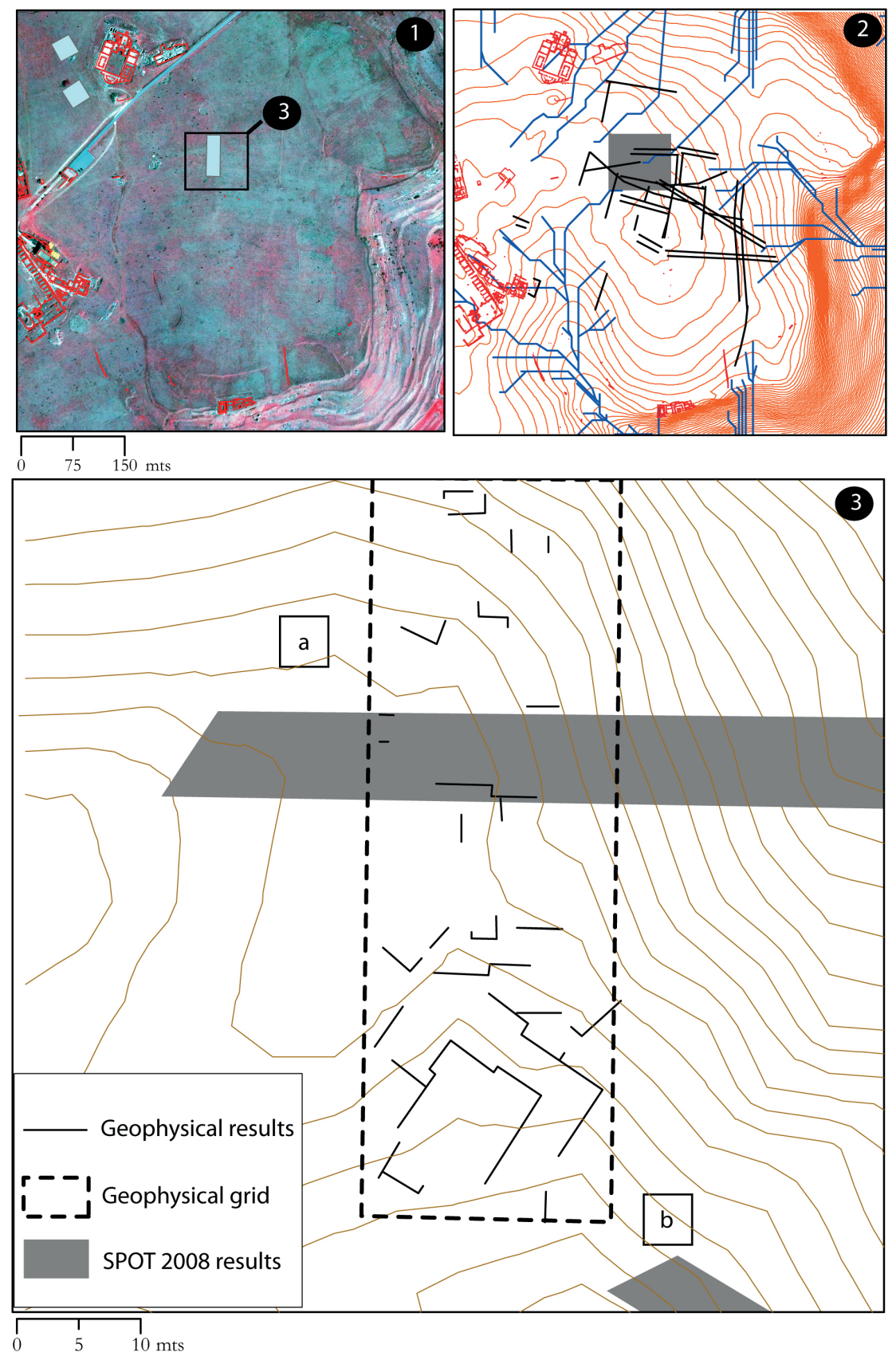

Figure 14. 1) Geophysical Survey; 2) Interpretation of 2007 and 2008 SPOT traces, drainage network; 3) Survey interpretation of geophysical anomalies carried out by the company SOT and SPOT traces. 
interesting data that confirm the urban forms identified in this area.

The traces of some of the secondary drains, the anomalies found in the SPOT images, the SVF and Openness Positive analysis, and the results of the geophysical survey applied in our study area, show the existence of an organized system of streets and houses, in which the urban orientations known to date are maintained (Fig. 16 a, b, c), as well as a modulated urban area with N-S orientation (Fig. 16 d).

Regarding the known orientations, Figure 16 shows three major areas with overlapping orientations. In a), the orientation possibly corresponds to the first urbanization of the hill as a colonial city, with regular plots for housing. The monumental forum area occupying the top of the hill is shown in b). Although the location of the temple could be earlier, the consolidation of the square took place after the first division into plots. This change led to a third rule of orientation, which sought to harmonize the new buildings into a heterogeneous and complex urban plan. There was no new parcelling, but rather a reference between volumes in the urban landscape. As a result, the facade of the Los Arcos I baths occupy an available plot from the first phase of parcelling, in accordance with a different orientation - that of the buildings east of the forum. The rectangle shown in the image does not indicate a set of new traces of subdivision that have not been detected, but instead highlights the alignment of buildings that are distant from each other.

In addition, there is the new orientation outlined in Fig. 16d, probably prior to the building of the city. As a hypothesis, we can suggest the existence of a settlement before the development of the monumental city, which received the category of municipality in the times of Tiberius, and the status of a colonia afterwards. This rectangular enclosure, which coincides with the lines that Loperráez drew on the east side of the hill of Clunia in 1788, could therefore be the traces of an earlier settlement on the hill. The position of this space on the eastern slope of Clunia's plateau could be related to the extensive visibility of the surroundings, suggesting perhaps a settlement involved in territorial control.

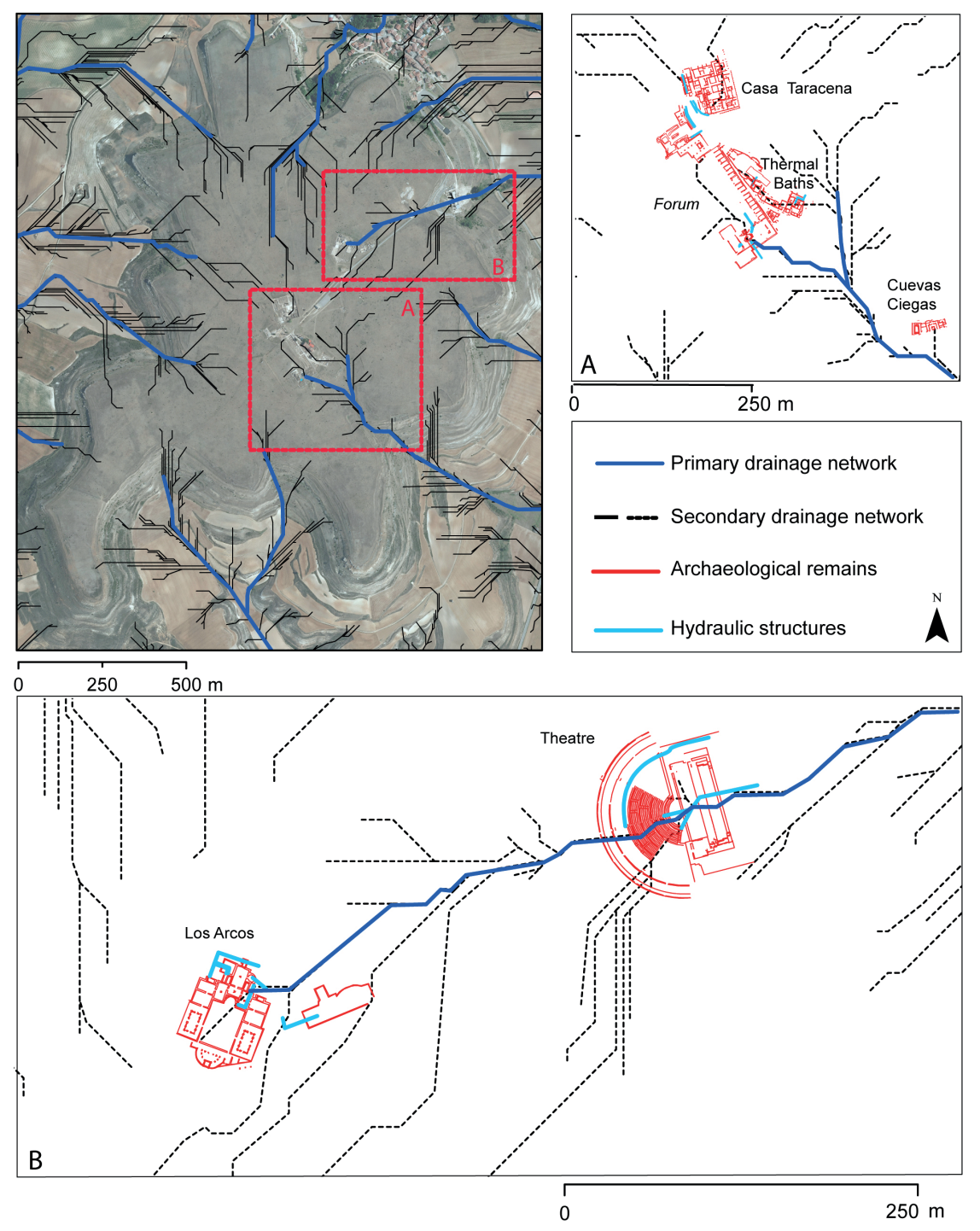

Figure 15. Relationship between the main drainages obtained from the LDD map and the hydraulic archaeological structures. A) Theatre/Los Arcos/Arroyo de la Muñeca sector. B) Forum/ Paredejas/Cuevas Ciegas sector. 


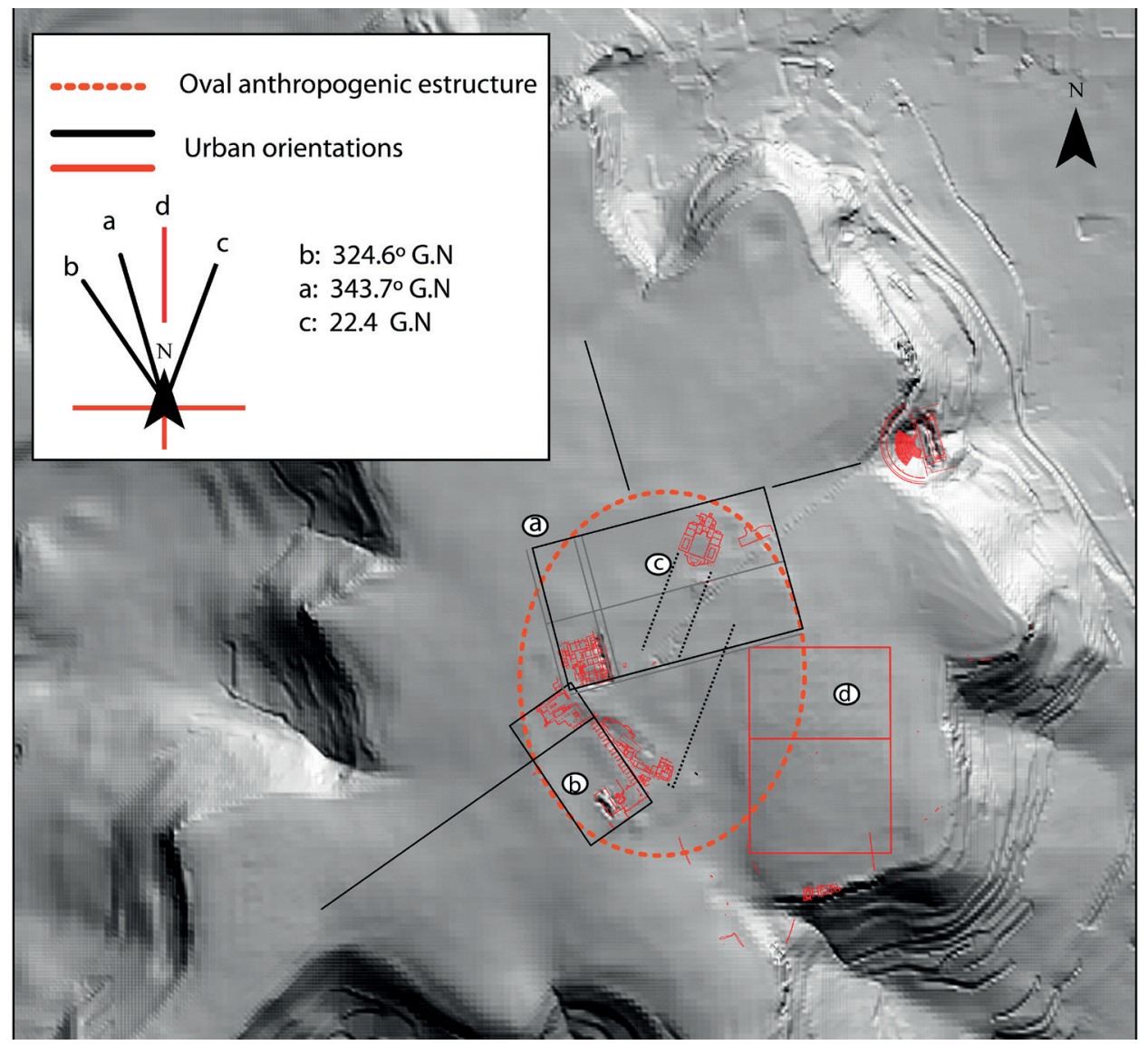

Figure 16. Different urban orientations. a) Urban structure based on the orientation of the theatre and the Casa Taracena buildings; b) Urban structure based on the orientation of the Forum; c) Urban structure based on the orientation of the Los Arcos thermal building; d) New urban structure detected using the different methods explained in the text. Sources: LIDARDEM (5m /pixel), Plan Nacional de Ortofotografía Aérea (PNOA).

As for the oval shape revealed by the DEM, the regularity of its configuration clearly means that it is not a natural topographic feature. Furthermore, the limits of the oval match up with the limits of the consolidated space of the city, including the major monuments, reinforcing the belief that its origin is anthropogenic. Interestingly, the oval and the rectangular forms intersect, meaning that an archaeological excavation should be able to accurately establish their relative chronology.

Without this confirmation, we suggested the hypothesis that the oval shape is a result of the transformation of the Roman city into a medieval village, which is reflected significantly in the design of Loperráez. In fact, written sources reveal that Clunia was a major fortress with towers at the time of the Arab conquest of the region by Berber Tariq ibn Ziyad in the early $8^{\text {th }}$ century. Muslim chroniclers referred to it when mentioning the passing of troops under the command of Tariq towards Amaya. The Annales Complutenses mention its re-conquest and re-population by The Count of Castile Gonzalo Fernández in 912, and that it subsequently fell to two Muslim attacks in 920 and 994, correspondingly. Aben-Adhari was the Muslim historian who compiled these facts in his book Al-Bayan-ul-Mogrib, and he noted that the troops of Caliph Abderrahman III found the city abandoned and defenceless.

\section{Conclusions}

The hydrological study performed using GIS allowed us to see definitely the relationship that could be established between the city's drains and access roads. Although these routes are the ones we know of today, and which remained until crops ceased to be grown on the hill, they might in some cases be the same as the access routes used in Roman times. Moreover, we have seen to what extent the land retains a memory of ancient courses. To do this, we analysed the relationship between the drains and channels-sewers, which we know of from the archaeological work. Finally, there is the confirmed relationship between these drains and the urban planning of the city.

Through different methods applied to various information sources (DEM, SPOT scenes, Geophysical Survey, Wetness Index, Drainage Analysis, Lidar Visualization Tools) there is an area of the site where the structures have a new orientation now (NS), diverging with those of the rest of the excavated structures (Theatre, Forum, Paredejas, etc). As it is presented, we might infer that it could correspond to a first, earlier Roman settlement, before the rise of the city.

The oval shape detected in the results of the Hillshade function could be the transformation and reduction at the top of the hill in late antiquity or 
in the early medieval era, taking advantage of its largest monuments to reshape the city at the time of its decline.

All of these - geophysical studies, flow accumulation and distribution studies, the digital elevation model, slope analysis, infrared images, wetness index, and remote sensing - delivered a perspective of Clunia that was previously unknown at ground level. The use of a high-resolution digital elevation model (DEM) in the calculation of the flow direction and accumulation map, revealed a series of data that would have been impossible to evaluate directly on the ground, or by means of aerial photography.

We believe that the predictive ability of the wetness indices should provide results similar to those expected in an analysis performed under optimal conditions by means of photo interpretation and remote sensing. In other words, this is an analysis based on hygrometry and damp marks. TWI should therefore anticipate the water anomalies inherent in the detection of archaeological structures. Thus, in regard of these assumptions, we believe that the application of the three indices in a micro-topography study should produce results similar to those anticipated for large areas of terrain, and, therefore, all three were applied to our study area.

This work emphasizes the increasingly demonstrated usefulness of a multidisciplinary approach to the ancient landscape, and non-invasive prospecting for the study of any urban grid.

We believe that the methodology applied with multidisciplinary approaches provides new exploratory functions, and increases the effectiveness of known ones. For example, the analysis of the drain's network (LDD), along with known archaeological data, contribute to understanding the urban organization and water management of Clunia, symbiotically linked to Cueva Román, as seen previously. And, although the calculated Wetness Indexes do not provide more detailed information, there is enough evidence to conclude that a higher resolution DEM (centimetre instead of 5 meters/pixel) will provide better results than the analytical micro-topography. Now, we start evaluating the capabilities of these indexes to simulate moisture retention. The use of indexes will then equal the study of NIR bands of satellite imagery or aerial photography. However, these sources should be obtained in very specific environmental conditions, which are not always easy to reproduce with satisfactory results.

The Remote Sensing analysis has been applied mainly on SPOT images, developing its analysis by analytical functions such as PCA or NVDI. Of course, there are multispectral satellite images with higher resolution, and including a larger number of bands (QuickBird, WorldView 2,3,4) and capabilities, as compared to those used by our research group (Fiz, Subías, and Cuesta 2012). But the economic costs of such information in a period of economic crisis as the current, require offering alternatives that would prove economically viable. The authors can confirm that this study was conducted at virtually zero cost, if we do not consider the staff's wages involved. Finally, and as expected, the combination of multiple approaches provided the most satisfactory results.
Rosa Cuesta Diputación de Burgos Monasterio de San Agustín, c. Madrid 25, 09002 Burgos

Ignacio Fiz

Universitat Rovira i Virgili Institut Català d'Arqueologia Clàssica URV, Av. Catalunya 35, 43003 Tarragona

Eva Subias

Universitat Rovira i Virgili URV, Av. Catalunya 35, 43003 Tarragona

Francesc Tuset

Equip de recerca d'Arqueologia i Arqueometria de la Universitat de Barcelona, University of Barcelona ERAAUB, c. Montalegre 6, 08001 Barcelona

Miguel Ángel de la Iglesia Universidad de Valladolid Av. Salamanca, s/n, 47014 Valladolid

Rebut: $21 / 12 / 2018$

Acceptat: 15/04/2019 
Alexakis, D., Sarris, A., Astaras, T., Albanakis. K. (2011). Integrated GIS, remote sensing and geomorphologic approaches for the reconstruction of the landscape habitation of Thessaly during the Neolithic period. Journal of Archaeological Science, 38: 89-100.

Álvarez Martínez, J. M., Nogales Basarrate, T. (2004). Programas decorativos del Foro Colonial de Augusta Emerita. El Templo de Diana - Templo de Culto Imperial. In: Ramallo Asensio, S. F. (ed.). La decoración arquitectónica en las ciudades romanas de Occidente, Actas del Congreso Internacional celebrado en Cartagena (8-10 octubre 2003). Universidad de Murcia. Murcia: 293-320.

Boehner, J., Koethe, R., Conrad, O., Gross, J., Ringeler, A., Selige, T. (2002). Soil Regionalisation by Means of Terrain Analysis and Process Parameterisation. In: Micheli, E., Nachtergaele, F., Montanarella, L. (eds.). Soil Classification 2001. European Soil Bureau, Research Report No. 7, EUR 20398 EN. Luxembourg: 213-222.

Bock, M., Böhner, J., Conrad, O., Köthe, R. and Ringeler, A. (2007). Methods for creating functional soil databases and applying Digital Soil Mapping with SAGA GIS. In: Hengl, T., Panagos, P., Jones, A. and То́тн, G. (eds.). Status and prospect of soil information in South-Eastern Europe: Soil databases, projects and applications. European Commission, Directorate General Joint Research Centre, Institute for Environment and Sustainability. Ispra: 149-189.

Böhner, J., McCloy, K. R., Strobl, J. (eds.) (2006). SAGA - Analysis and Modelling Applications. Göttinger Geographische Abhandlungen Heft 115, Verlag Erich Goltze GmbH. Göttingen.

Brown, A. G. (2008). Geoarchaeology, the fourdimensional (4D) fluvial matrix and climatic causality. Geomorphology, 101: 278-297.

Calvo, I. (1916). Excavaciones en Clunia. Memorias de la Junta Superior de Excavaciones y Antigüedades, Volumen 3. Madrid.

Conolly, J., LaKe, M. (2006). Geographical Information Systems in Archaeology. Cambridge.

Costa-Cabral, M. C., Burges, S. J. (1994). Digital elevation model networks (DEMON): A model of flow over hillslopes for computation of contributing and dispersal areas. Wat. Resour. Res., 30: 1681-1692.

Costa, J. M., Fonte, J., Menéndez, A., González, D., Gago, M., Blanco-Rotea, R., Álvarez, V. (2016a). Roman military settlements in the Northwest of the Iberian Peninsula. The contribution of historical and modern aerial photography, satellite imagery, and airborne LiDAR. AARGnews, 52: 43-51.
Costa, J. M., Fonte, J., Menéndez, A., González, D., Gago, M., Blanco-Rotea, R., Álvarez, V. (2016b). Hallazgos arqueológicos recientes para el estudio de la presencia militar romana en el oriente gallego. GALLAECIA, 35: 39-70.

Crouch, D. P. (1993). Water Management in Ancient Greek Cities. Oxford University Press. New-York/Oxford.

Cuesta, R. (2012a). Cueva Román: Fuente de abastecimiento-Lugar de culto de la Colonia Clunia Sulpicia. In: Costa, A., Palahí, Ll., Vivó, D. (eds.). Aquae Sacrae. Agua y sacralidad en la antigüedad. Actas de la reunión internacional (Girona, Julio 12-13, 2011). Institut de Recerca Històrica de la Universitat de Girona: 167-180.

Cuesta, R. (2012b) (unpublished). Recursos hídricos, sistema kárstico y gestión del agua en la Colonia Clunia Sulpicia. Tesis doctoral. ICAC. Tarragona.

De la Iglesia, M. A., Tuset, F. (2012). Colonia Clunia Sulpicia. Ciudad Romana. Diputación Provincial. Burgos.

De Palol, P. et al. (1991). Clunia o. Studia varia cluniensia. Diputación Provincial. Burgos.

De Palol, P., Guitart, J. (2000). Los Grandes conjuntos públicos. El foro colonial de Clunia. Clunia VIII. Diputación Provincial. Burgos.

Dabas, M., Deletang, H., Ferdiere, A., Jung, C., and Zimmerman, W. H. (2006). La Prospection. Editions Errance. París.

Díez-Martin, F. (2010). Evaluating the effect of plowing on the archaeological record: The early middle Palaeolithic in the river Duero basin plateaus (north-central Spain). Quaternary International, 214: 30-43.

Fiz, I., Subías, E., Cuesta, R. (2012). Deconstructing and reconstructing the landscape of Oxyrhynchus using Textual Sources, Cartography, Remote Sensing and GIS. In: Chrysanthi, A., Murrieta, P., Papadopoulos, C. Thinking beyond the Tool: Archaeological Computing \& the Interpretive Process. Proceedings of the TAG201.32nd annual meeting of the Theoretical Archaeology Group (Bristol, 17th-19th Dec 2010). British Archaeological Reports. Archaeopress. Oxford: 131-154.

Font Tullot, I. (1983). Atlas Climático de España. Ministerio de Transportes, Turismo y Comunicaciones. Instituto Nacional de Meteorología. Madrid.

Fowler, M. J. F. (1993). Stonhenge from space. Spaceflight, 35: 130-132.

Fowler, M. J. F. (1995). Detection of archaeological features on multispectral satellite imagery. AARGNews, 10: 7-14. 
FreEman, T. G. (1991). Calculating catchment area with divergent flow based on a regular grid. Computers and Geosciences, 17(3): 413-422.

Garbuzov, G. P. (2003). The use of space remote sensing for archaeological mapping of the Tarman Peninsula, Russia. Archaeologia Polona, 14: 176-177.

Gutiérrez, M. A., De la Iglesia, M. A., Subías, E., Tuset, F. (2006). El teatro de Clunia. Nuevas aportaciones. In: Márouez, C., Ventura, A. (eds.). Jornadas sobre teatros romanos en Hispania (Córdoba 2002). Córdoba: 291-310.

Hinojal, V. (1913). Apuntes acerca de las ruinas de Clunia. Boletín de la Sociedad Española de Excursiones. Madrid: 222-244.

JimÉnez-SÁnchez, M., GonZÁlez-Álvarez, I., ReQuejoPagés, O., Domínguez-Cuesta, M. J. (2011). Enhancing rescue-archaeology using geomorphological approaches: Archaeological sites in Paredes (Asturias, NW Spain). Geomorphology, 132(3-4), 15: 99-110.

Kokalu, Z., Hesse, R. (2017). Airborne laser scanning raster data visualization: A Guide to Good Practice. Založba ZRC. Ljubljana.

LEE, J. (1980). Digital image enhancement and noise filtering by use of local statistics. In: IEEE transactions on pattern analysis and machine Intelligence, Vol PAMI2. No 2: 165-168.

Loperráez Corvalan, J. B. (1788). Descripción Histórica del Obispado de Osma. Vol. II. Imprenta Real. Madrid.

Mar, R., Ruiz de Arbulo, J. (2011). Tarragona Romana: República y Alto Imperio (218 aC-260 dC). In: Història de Tarragona I. Diputació Provincial. Tarragona: 207-538.

Masini, N., Terenzio, F., Biscione, M., Fundone, V., Sedile, M., Sileo, M., Pecci, A., Lacovara, B., Lasaponara, R. (2018). Medieval Archaeology Under the Canopy with LiDAR. The (Re)Discovery of a Medieval Fortified Settlement in Southern Italy, Remote Sens. 2018, 10, 1598; doi:10.3390/rs10101598.

Merola, P., Allegrini, A., Fuglietta, D., Sampieri, S. (2006). Using vegetation indices to study archaeological areas. British Archaeological Reports International Series 1568. Archaeopress. Oxford: 303-310.

Moore, I. D., Grayson, R. B., Ladson, A. R. (1991). Digital terrain modelling: a review of hydrological, geomorphological, and biological applications. Hydrological Processes, vol. 5: 1.

Moore, I. D., Gessler, P. E., Nielsen, G. A., Peterson, G. A. (1993). Soil Attribute Prediction Using Terrain Analysis. Soil Sci. Soc. Am. J., 57: 443-452.

O'Callaghan, J. F., Mark, D. M. (1984). The extraction of drainage networks from digital elevation data. Computer Vision, Graphics and Image Processing, 28: 323-344.
OlaYa, V. (2004a). A gentle introduction to SAGA GIS. The SAGA User Group e.V. Gottingen. Germany.

Olaya, V. (2004b). Hidrología Computacional y Modelos Digitales del Terreno, http://heart.sf.net/textos.

Olaya, V., Conrad, O. (2009). Geomorphometry in SAGA. Developments in Soil Science, 33: 293-308.

PAPAdAKIS, J. (1966). Climates of the world and their agricultural potentialities. Buenos Aires.

Rodriguez Fernández, L. R., Heredia, N. (dirs.) (2007). Mapa Geológico de España, Escala 1:50.000, Memoria. Hoja de Lerma (276). Instituto Geológico y Minero de España. Madrid.

Rowlands, A., Sarris, A. (2007). Detection of exposed and subsurface archaeological remains using multisensor remote sensing. Journal of Archaeological Science, 34: 795-803.

Stafford, J. D., Leigh, D., Asch, D. (1992). Prehistoric settlement and landscape change on alluvial fans in the Upper Mississipi River valley. Geoarchaeology, 7 (4): 287-314.

Subías, E., FIz, I. (2012). Teledetección y paisaje: aproximación al entorno de Oxirrinco (el Minia, Egipto). In: IV Congreso Ibérico de Egiptología (Lisboa 13-17 setiembre 2010). ICAC. Lisboa: 1142-1157.

Subías, E., Fiz, I., Cuesta, R. (2011). Elementos del paisaje del nomo oxirrinquita. In: Subías, E., Azara, P., Carruesco, J., Fiz, I., Cuesta, R. (eds.). The GrecoRoman space of the city in Egypt: image and reality. Institut Català d'Arqueologia Clàssica. Sèrie Documenta 22: $187-210$.

Tarboton, D. G. (1997). A New Method for the Determination of Flow Directions and Contributing Areas in Grid Digital Elevation Models. Water Resources Research, 33(2): 309-319.

Traviglia, A., Cottica, D. (2011). Remote sensing applications and archaeological research in the Northern Lagoon of Venice: the case of the lost settlement of Constanciacus. Journal of Archaeological Science, 38: 2040-2050.

VALDÉs, L., REINA, F. J. (2004). Informe de la investigación del Sistema Kárstico del Cerro de Clunia y de la Geología local y regional. Método Directo y Método Geofísico. Peñalba de Castro (Burgos). Inédito, en Depósito Biblioteca del Yacimiento Arqueológico C.C.S.

VALDÉs, L., ReINA, F. J. (2006). Informe de la investigación por Método Geofísico para la localización de la Atarjea de Drenaje del Teatro de Clunia, Peñalba de Castro (Burgos). Inédito, en Depósito en la Biblioteca del Yacimiento Arqueológico C.C.S.

Valdés, L., Tuset, F., Reina, J., FarJas, M. (2004). Colonia Clunia Sulpicia. In: CaIn, K., Chrysanthou, Y., Niccolucci, F., Silberman, N. (eds.). The 5th 
R. Cuesta, I. Fiz, E. Subias, F. Tuset, M. Á. de la Iglesia, Hydraulic and urban management during Roman times based on GIS...

International Symposium on Virtual Reality, Archaeology, and Cultural Heritage VAST (Oudenaarde, Belgium, December 7-10): 41-43.

Vogel, S., Märker, M. (2010). Reconstructing the Roman topography and environmental features of the
Sarno River Plain (Italy) before the AD 79 eruption of Somma-Vesuvius. Geomorphology, 115: 67-77.

Wilson, A. (2000). Drainage and Sanitation. In: WiKANDER, Ö. (ed.). Handbook of Ancient Water Technology. Brill. Leiden. 